\title{
THERMOMINERAL WATERS OF INNER DINARIDES KARST
}

\section{TERMOMINERALNE VODE KRASA NOTRANJIH DINARIDOV}

\author{
Dejan MILENIĆ ${ }^{1}$, Olivera KRUNIĆ1 \& Djuro MILANKOVIĆ
}

\begin{abstract}
UDC 556.3:551.435.8(234.42)

Dejan Milenić, Olivera Krunić \& Djuro Milanković: Thermomineral waters of inner Dinarides Karst
\end{abstract}

The Dinarides are the largest continuous karst region in Europe. With regard to a geotectonic view, they are divided into the Outer, Central and Inner Dinarides occupying the territories of Slovenia, Croatia, Bosnia and Herzegovina, Serbia and Montenegro. Numerous occurrences of thermomineral water have been recorded in the Inner Dinarides area. The majority of them are genetically related to carbonate sediments of Mesozoic age. This paper deals with occurrences of thermomineral waters of the Inner Dinarides karst, their quantitative and qualitative characteristics, basic genetic types, the age of karst thermomineral waters of the Inner Dinarides, the available quantities of hydrogeothermalmineral energy, balneological potential and the possibility of rational multi-purpose utilisation. Hydrochemical and isotope methods have been used for the analysis of basic genetic types and age of karst thermomineral waters, while a geothermometer method has been used for the calculation of primary temperatures in water-bearing horizons(geothermal reservoirs) themselves. The carried out research has pointed out that karst thermomineral waters formed in carbonate sediments of Mesozoic age are characterized by temperatures ranging from $15.5^{\circ} \mathrm{C}$ (Knežina Ilidža) to $75^{\circ} \mathrm{C}$ (Bogatić), being most frequently of a $\mathrm{HCO}_{3}^{-} \mathrm{Ca}, \mathrm{Mg}$ type with neutral to poor alkaline reaction and mineralization below $1 \mathrm{~g} / \mathrm{l}$. Karst thermomineral waters of the Inner Dinarides are most frequently related to geothermal systems formed in carbonate sediments covered by rocks of poor water permeability. In case of some thermomineral water occurrences, the mixing of the karst thermomineral waters with those formed in sedimentary basins occurs due to their hydraulic relation, thus it is not possible to determine only one geothermal system in which they are formed. The overall geothermal potential of the thermomineral waters of the Inner Dinarides karst is about $160 \mathrm{MW}$. In addition to the geothermal aspect, these waters

\section{Izvleček \\ UDK 556.3:551.435.8(234.42) \\ Dejan Milenić, Olivera Krunić \& Djuro Milanković: Termomi- neralne vode krasa Notranjih Dinaridov}

Dinaridi so največje zvezno kraško območje v Evropi. Z geotektonskega vidika so razdeljeni na Zunanje, Centralne in Notranje Dinaride, ki se raztezajo preko ozemelj Slovenije, Hrvaške, Bosne in Hercegovine, Srbije in Črne Gore. Na območju Notranjih Dinaridov so bili zabeleženi številni pojavi termomineralne vode, njihove količinske in kakovostne značilnosti, osnovni razvojni tipi, starost termomineralne vode Notranjih Dinaridov, razpoložljive količine za hidrogeotermomineralno energijo, balneološki potencial in možnost za racionalno večnamensko izrabo. Hidrokemične in izotopske metode so bile uporabljene za analizo razvojnega tipa in starost kraških termomineralnih voda, in za izračun primarnih temperatur $\mathrm{v}$ vodonosnih plasteh (geoteralnih rezervoarjih) je bila uporabljena geotermometrska metoda. Izvedena študija je pokazala, da termomineralne vode, ki se nahajajo $\mathrm{v}$ karbonatnih sedimentih mezocojske starosti, označujejo temperature med $15.5^{\circ} \mathrm{C}$ (Knežina Ilidža) in $75^{\circ} \mathrm{C}$ (Bogatić), so najpogosteje tipa $\mathrm{HCO}_{3}^{-} \mathrm{Ca}, \mathrm{Mg}$ z nevtralno do šibko alkalno reakcijo in mineralizacijo pod $1 \mathrm{~g} / \mathrm{l}$. Kraške termomineralne vode Notranjih Dinaridov so najpogosteje povezane z geotermalnimi sistemi, ki so se oblikovali v karbonatnih sedimentih in so prekriti s slabo prepustnimi kamninami. Občasno se nekatere kraške termomineralne vode zaradi hidravličnih povezav mešajo $\mathrm{s}$ tistimi, ki so nastale $\mathrm{v}$ sedimentarnih bazenih. Tako ni mogoče natančno določiti le enega geotermalnega sistema, od koder vode izvirajo.skupni geotermalni potencial termomineralnih voda Notranjih Dinaridov je okoli 160 MW. Poleg geotermalnega vidika, so te vode pogosto izrabljene v balneološke namene, za wellness programe in za ustekleničenje. Stopnje raziskovalnih aktivnosti in s tem načini izrabe so zelo različni. Glede na število znanih virov in njihovega potenciala lahko $\mathrm{z}$ gotovostjo trdimo, da se bo $\mathrm{v}$ prihodnosti izraba termomineralnih voda, ki se pojavljajo na krasu Notra-

\footnotetext{
${ }^{1}$ University of Belgrade, Faculty of Mining \& Geology, Dept. Of Hydrogeology, Djusina 7, 11000 Belgrade, Serbia, e-mail:dmilenic@yahoo.ie,krunico@open.telekom.rs,djuro2703@yahoo.com
}

Received/Prejeto: 14.5.2012 
have been widely utilised in balneology, wellness programmes, as well as for the needs of bottling. The level of research activity and with that the way of the utilisation of these waters are various. With regard to the number of occurrences known so far and their potential, it can be claimed with certainty, that the utilisation of thermomineral water occurring in the karst of the Inner Dinarides will increase significantly in future. An example of the multi-purpose utilisation of the Pribojska Banja Spa thermomineral waters illustrates a possible way of doing it.

Key words: karst, Inner Dinarides, thermomineral water, multi-purpose utilisation. njih Dinaridov občutno povečala. Primer večnamenske izrabe termomineralne vode v zdraviliškem kraju Pribojska Banja nakazuje te možnosti.

Ključne besede: kras, Notranji Dinaridi, termomineralna voda, večnamenska izraba.

\section{ACTUALITY AND APPLIED METHODOLOGY OF THERMOMINERAL WATER EXLORATION}

Thermomineral water occurrences and deposits of the Inner Dinarides karst are valuable natural resource based on their wide distribution, physico-chemical characteristics, geothermal potential and the presence of active balneological components. With regard to the numerous occurrences, and the level of research activity, the nonhomogeneity within the borders of the region should be emphasised.

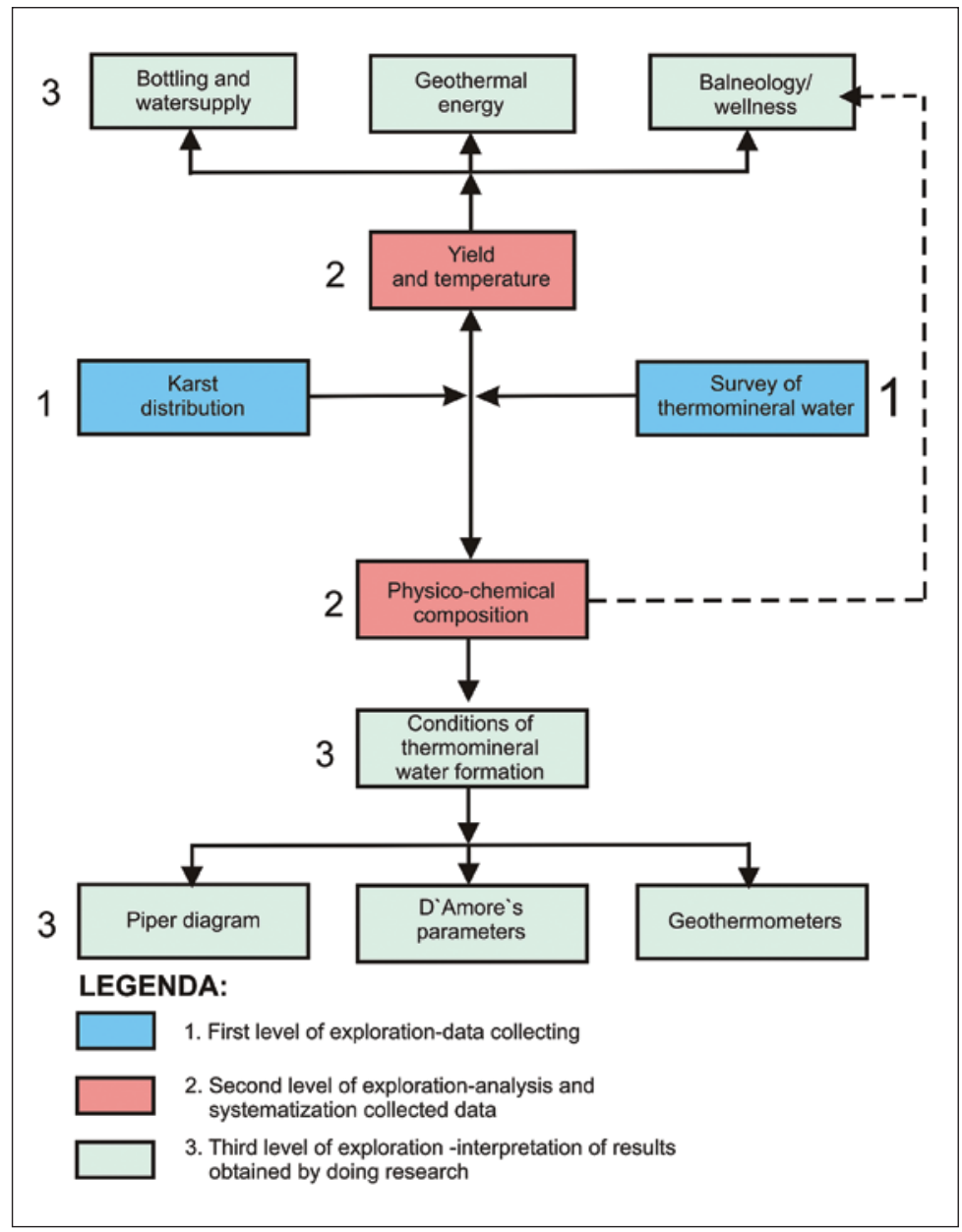

Fig. 1: Applied exploration methodology of karst thermomineral waters of Inner Dinarides.
For the needs of these explorations, thermomineral waters are treated as groundwaters which on the basis of the increased temperature, mineralization, and the general chemical and gaseous composition, the content of specific components or radio active elements differ from "ordinary" low mineralized waters (Dragišić 1997).

Hydrogeological explorations that have preceded the completion of this paper are generally divided into three levels (Fig. 1). Within the first level, the study area has been delineated and data on occurrences of karst thermomineral water in the Inner Dinarides region collected. Within the second level, the classification and systematization of collected data have been carried out, and within the third level, the interpretation of obtained results has been carried out in terms of the analysis of formation conditions of thermomineral water of the Inner Dinarides karst as well as the analysis of the water multi-purpose utilisation possibility

The data obtained by carrying out the mentioned explorations point out real possibilities for planned and systematic explorations for the needs of rational complete utilisation of thermomineral waters of the Inner Dinarides karst. Rational multi-purpose utilisation of these waters is shown in the example of thermomineral water of the Pribojska Banja Spa. 


\section{KARST DISTRIBUTION WITHIN INNER DINARIDES}

Major part of the Dinarides is made of carbonate sediments of Mesozoic age (Cvijić 1924; Herak 1977; Aubouin 1974; Mijatović 1984; Andjelković 1988; Dimitrijević 1995; Radulović 2000; Kranjc 2004). Carbonates of Cretaceous age prevail in the Outer Dinarides, whereas Triassic carbonate sediments prevail in the Central and Inner Dinarides. Numerous occurrences of thermomineral water in the Inner Dinarides region are related to carbonate sediments of Mesozoic age.

The surface of the Inner Dinarides is $37,000 \mathrm{~km}^{2}$. Karst is discovered on 3,700 $\mathrm{km}^{2}$. In Fig. 2, there are shown parts of the terrain where karst is discovered at the surface of the terrain in the Inner Dinarides region.

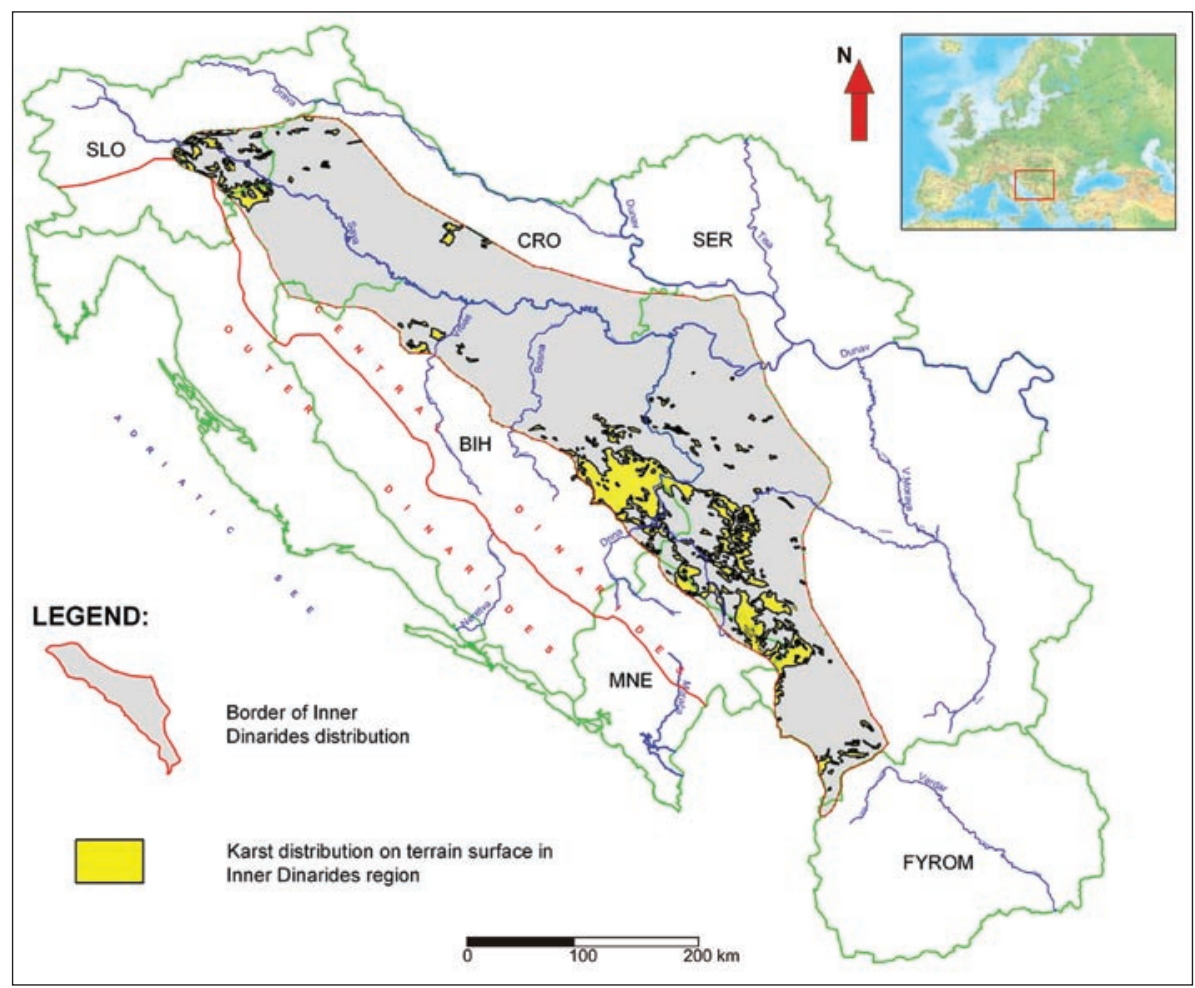

Fig. 2: Distribution of Inner Dinarides with marked zones of discovered karst.
Bosnia and Herzegovina (Čičić et al. 1986). Carbonate sediments were discovered at the surface of the terrain in the vicinity of Banja Luka and in the wider area of Romania Mt. and Devetka. In the region of Serbia, Dinaric karst is mostly developed in the limestone of Upper and Middle Triassic characterised by pronouncedly carbonate composition and a high degree of tectonic damage. Compared with Triassic limestone, the Upper Cretaceous one shows lesser distribution and occurs in the shape of isolated masses (Stevanović 1995). Triassic limestone in the region of Serbia can be followed from Fruška Gora Mt., where it stretches southwest, namely to the Sava Valley and the Mačva region where it is covered by younger Neogene and Quaternary sediments. Triassic limestone occurs again at the surface of the terrain in the region of Valjevo-Mionica karst (Lelići karst) in which significant thermomineral water reserves were formed. The Drina-Ivanjica element represented by rocks of $\mathrm{Pal}$ aeozoic age and the ophiolite belt divides carbonate complexes of Valjevo- Mionica karst from the carbonate complex of the Ovčar Banja Spa, namely southwest of the carbonate complexes of Tara, Zvijezda, Zlatibor, Zlatar, Čemernica and the Pešter plateau. Dinaric karst is developed in the watershed of the Beli Drim River where it stretches in northwest and south border of the Metohia plain (Filipović et al. 2005). On the territory of Mon-
Viewed from the strike northwest to southeast, sediments of Mesozoic age occur at the surface in the shape of isolated parties covered by younger Neogene, namely Quaternary sediments. Triassic limestone was discovered at the line from Novo mesto to Samobor, and south of Varaždin. Going eastward, carbonate sediments encounter the area of Horst Mountains in Slavonia (Kosmat 1924; Petković 1961; Andjelković 1980). South of the Sava valley, carbonate sediments are in tectonic relation to the ophiolote belt dividing the Central from the Inner Dinarides in the wider area of tenegro, karst terrains are developed in limestone of Triassic, Jurassic and Cretaceous age. In the maritime zone, namely in the Outer Dinarides zone, Cretaceous limestone is mostly distributed, whereas Triassic limestone, as in case of Serbia and Bosnia and Herzegovina, is mostly distributed in the Inner Dinarides region, namely in northern part of Montenegro (Radulović 2000). In addition to its spreading at the surface of the terrain, carbonate sediments are also distributed in the area of the Inner Dinarides below younger most frequently Tertiary and Quaternary sediments. 


\section{SURVEY OF KARST THERMOMINERAL WATER OCCURRENCES OF INNER DINARIDES AND BASIC WAYS OF THEIR UTILISATION}

The area of the Inner Dinarides is characterised by the carbonate complex overlayer of Mesozoic age, which has resulted in the precondition for the formation of half open and half closed hydrogeological features where thermomineral water has been formed. The majority of

Tab. 1: Survey of thermomineral water of Inner Dinarides.

\begin{tabular}{l|l|l|l|l|l}
\hline No. & Name of occurrence & Country & No. & Name of occurrence & Country \\
\hline 1. & Dolenjeske Toplice Spa & Slovenia & 25. & Debrc & Serbia \\
\hline 2. & Jezero pri Družinski vasi & Slovenia & 26. & Dublje & Serbia \\
\hline 3. & Klevevž & Slovenia & 27. & Bogatić & Serbia \\
\hline 4. & Kostanjevica on Krka & Slovenia & 28. & Banja Koviljača Spa & Serbia \\
\hline 5. & Šmarješke Toplice Spa & Slovenia & 29. & Paune & Serbia \\
\hline 6. & Čatež & Slovenia & 30. & Mionica & Serbia \\
\hline 7. & Varaždinske Toplice Spa & Croatia & 31. & Vrujci Spa & Serbia \\
\hline 8. & Krapinske Toplice Spa & Croatia & 32. & Petnica & Serbia \\
\hline 9. & Stubičke Toplice Spa & Croatia & 33. & Banjci Kosjerić Spa & Serbia \\
\hline 10. & Sveta Helena (Šmidhen) & Croatia & 34. & Ovčar BanjaSpa & Serbia \\
\hline 11. & Tuheljske Toplice Spa & Croatia & 35. & Lađevac & Serbia \\
\hline 12. & Dvorovi & BH & 36. & Stapari & Serbia \\
\hline 13. & Višegradska Banja Spa & BH & 37. & Bioštanska Banja Spa & Serbia \\
\hline 14. & Olovo Banja Spa & BH & 38. & Roška Banja Spa & Serbia \\
\hline 15. & Olovo Solun & BH & 39. & Banja Vapa Spa & Serbia \\
\hline 16. & Olovo Orlje & BH & 40. & Gostilje & Serbia \\
\hline 17. & Knežina Ilidža & BH & 41. & Visočka Banja Spa & Serbia \\
\hline 18. & Budimlja Ilidža & BH & 42. & Pribojska Banja Spa & Serbia \\
\hline 19. & Banja Luka-Slatina & BH & 43. & Crno vrelo & Serbia \\
\hline 20. & Mala Kladuša & BH & 44. & Čedovo & Serbia \\
\hline 21. & Čarakovo & BH & 45. & Rudnik Banja Spa & Serbia \\
\hline 22. & Laktaši & BH & 46. & Studenica & Serbia \\
\hline 23. & Vrdnik & Serbia & 47. & Čečevo & Serbia \\
\hline 24. & Ljuba & Serbia & 48. & Pećka Banja Spa & Serbia \\
\hline & & & & \\
\hline
\end{tabular}

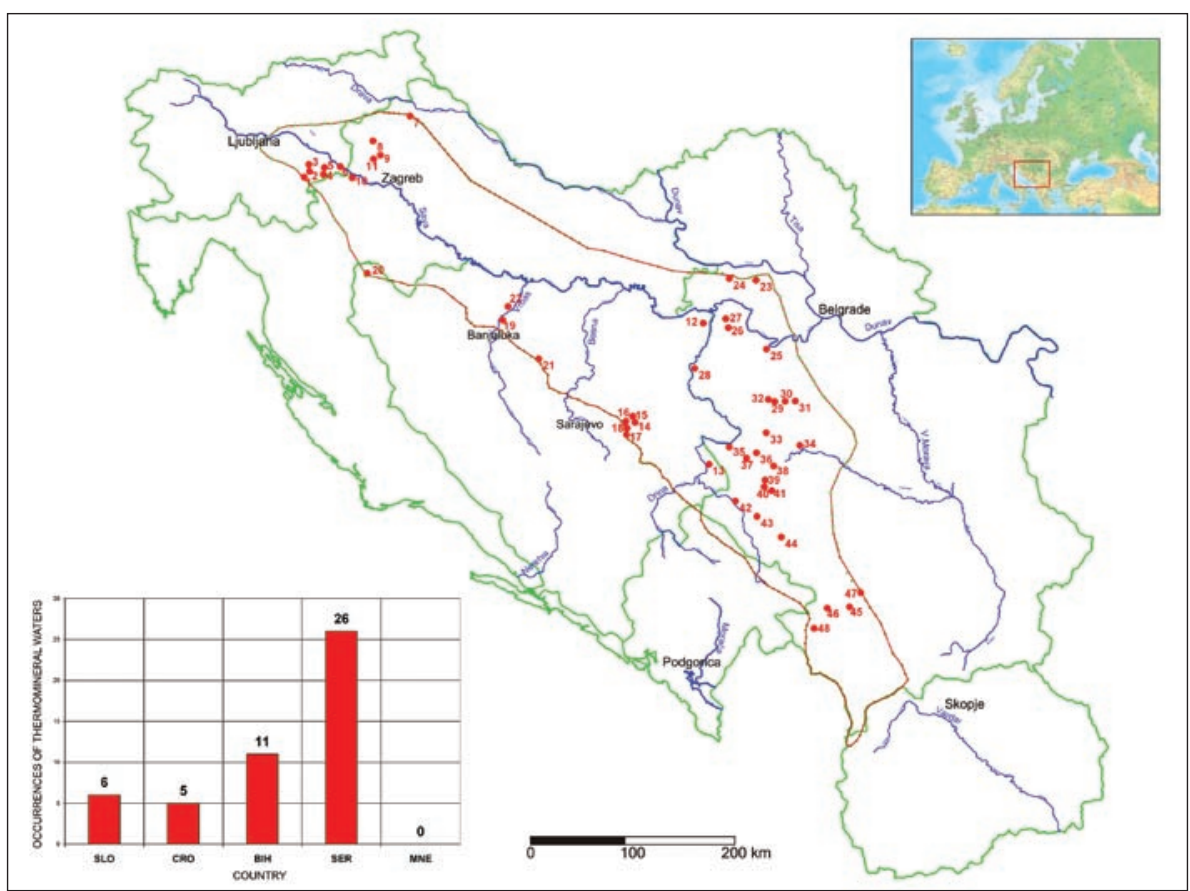

thermomineral water occurrences in the Inner Dinarides area are related to a karst aquifer formed in the Mesozoic carbonate rock complex (Tab. 1, Fig. 3). Occurrences of karst thermomineral water of the Inner Dinarides differ in yield, temperature, physical properties, chemism, age, etc., thus their classification is hard and complicated.

According to the evaluation carried out for the needs of this paper, the region of the Inner Dinarides karst has over $1200 \mathrm{l} / \mathrm{s}$ of thermomineral water with the temperatures ranging from $15.5^{\circ} \mathrm{C}$ to $75^{\circ} \mathrm{C}$. 48 occurrences of thermomineral water distributed in four states can be used for various purposes:

Balneological needs and wellness - karst thermomineral waters of the Inner Dinarides are widely used in balneology (Tab. 2), in addition to traditional utilisation for balneological purposes; the trend of thermomineral water utilisation for wellness programmes has grown recently.

Geothermal energy significant yield and temperature of these waters represent great potential from the point of view of utilisation of hydrogeothermal energy (about $160 \mathrm{MW}$ ).

Bottling and water supply - there are also numerous examples of Dinaric karst thermomineral groundwater utilisation for bottling needs.

Fig. 3: Detailed map of thermomineral water position of Inner Dinarides karst. 
Tab. 2: Balneological characteristics of some karst thermomineral waters of Inner Dinarides.

\begin{tabular}{|c|c|c|c|c|c|c|c|c|c|c|c|c|c|c|c|c|c|}
\hline Indications & 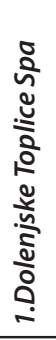 & 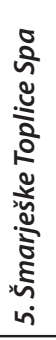 & 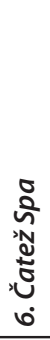 & 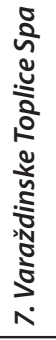 & 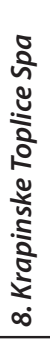 & 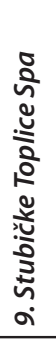 & 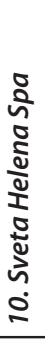 & 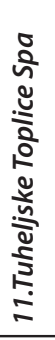 & 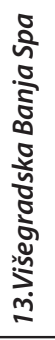 & 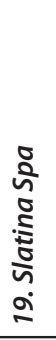 & 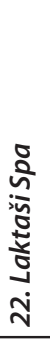 & 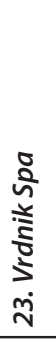 & 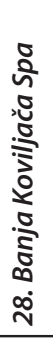 & 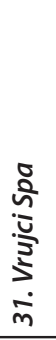 & 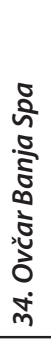 & 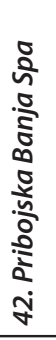 & 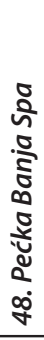 \\
\hline Heart and circulatory diseases & $\bullet$ & $\bullet$ & & & & & & & & $\bullet$ & $\bullet$ & & $\bullet$ & & & & \\
\hline Rheumatic & $\bullet$ & $\bullet$ & $\bullet$ & $\bullet$ & $\bullet$ & $\bullet$ & $\bullet$ & $\bullet$ & $\bullet$ & $\bullet$ & $\bullet$ & $\bullet$ & $\bullet$ & $\bullet$ & $\bullet$ & $\bullet$ & $\bullet$ \\
\hline Injuries to the locum system & $\bullet$ & $\bullet$ & $\bullet$ & $\bullet$ & $\bullet$ & $\bullet$ & $\bullet$ & $\bullet$ & $\bullet$ & $\bullet$ & $\bullet$ & $\bullet$ & $\bullet$ & $\bullet$ & $\bullet$ & $\bullet$ & $\bullet$ \\
\hline Metabolic diseases & & & & & & & & & $\bullet$ & $\bullet$ & & & & $\bullet$ & & & \\
\hline Gynecological diseases & $\bullet$ & & $\bullet$ & & & & & & $\bullet$ & & & & $\bullet$ & $\bullet$ & & $\bullet$ & \\
\hline Kidney and urinary tract & & & & & & & & & & & $\bullet$ & & & & & & \\
\hline Neurological diseases & $\bullet$ & $\bullet$ & $\bullet$ & & & & & & & & & & $\bullet$ & $\bullet$ & $\bullet$ & & $\bullet$ \\
\hline Skin diseases & & & & & & & & & $\bullet$ & & & & $\bullet$ & $\bullet$ & & & \\
\hline Neurotic distorts & & $\bullet$ & & & & & & & $\bullet$ & & & & $\bullet$ & & $\bullet$ & & \\
\hline Respiratory ailments & & & & & & & & & $\bullet$ & & & & $\bullet$ & & & & \\
\hline
\end{tabular}

In most cases waters characterised by the mineralization of $<1 \mathrm{~g} / \mathrm{l}$ and the $\mathrm{HCO}_{3}-\mathrm{Ca}-\mathrm{Mg}$ type (Vrujci, Petnica, etc.) are in question. Thermomineral waters of the $\mathrm{Di}-$ naric karst in most cases have the mineralization below $1 \mathrm{~g} / \mathrm{l}$, which qualifies them for the needs of water supply as well.

\section{CONDITIONS OF THERMOMINERAL WATER FORMATION IN INNER DINARIDES KARST}

Formation conditions of thermomineral waters of Dinaric karst vary in relation to geological setting, tectonic characteristics and hydrogeological conditions of the environment. Carbonate sediments are in various super- positional and tectonic relations with surrounding rock masses, which conditioned various formation conditions of moving and discharging of thermomineral waters.

\section{PHYSICO-CHEMICAL CHARACTERISTICS OF THERMOMINERAL GROUNDWATER}

Physico-chemical properties of karst thermomineral water of the Inner Dinarides result from geological characteristics of this area and hydrogeological, namely hydrochemical conditions of the environment in which the water is formed. In the Inner Dinarides area, there were analised 48 occurrences of thermomineral water varying in temperature, mineralization, basic anioncation composition, age, etc. Both in Tab. 3 and Fig. 4, there is presented a survey of basic physico-chemical properties and isotope characteristics of karst thermomineral waters of the Inner Dinarides, as well as the level of research activity. To form parts of Tab. 3, there were used data of (Čvorović 1970; Group of au- thors 1976; Protić 1995; Filipović 2003; Šimunić 2004; Lapanje 2006).

The temperature of karst thermomineral waters in the Inner Dinarides ranges from $15.5^{\circ} \mathrm{C}$ (Knežina-Ilidža) to $75^{\circ} \mathrm{C}$ (Bogatić).

44 occurrences of karst thermomineral waters of the Inner Dinarides have mineralization below $1 \mathrm{~g} / \mathrm{l}$. The following occurrences: Banja Luka-Slatina (2911 mg/l), Dvorovi (2104 mg/l), the Pećka Banja Spa (2040 mg/l) and the Banja Koviljača Spa (1400 mg/l) have the mineralization over $1 \mathrm{~g} / \mathrm{l}$.

According to the $\mathrm{pH}$ index the majority of karst thermomineral waters in the Inner Dinarides belong to 
Tab. 3: Survey of physico-chemical characteristics and age of thermomineral waters of Inner Dinarides karst (Sources: Čvorović 1970; Nosan 1973; Filipović 2003; Lapanje 2006; Šimunić 2004; Milenić 2010).

\begin{tabular}{|c|c|c|c|c|c|c|c|c|c|c|c|c|c|c|c|c|}
\hline & \multirow{2}{*}{ Spas } & $T$ & $M$ & $\mathrm{pH}$ & $\mathrm{HCO}_{3}^{-}$ & $\mathrm{SO}_{2}^{-}$ & $\mathrm{Cl}^{-}$ & $\mathrm{Na}^{+}$ & $K^{+}$ & $\mathrm{Ca}^{2+}$ & $\mathrm{Mg}^{2+}$ & $\mathrm{SiO}_{2}$ & \multirow{2}{*}{$\begin{array}{l}\text { Litho- } \\
\text { logy }\end{array}$} & \multirow{2}{*}{$\begin{array}{l}\text { Occu- } \\
\text { rence }\end{array}$} & \multirow{2}{*}{ Age $\left({ }^{14} \mathrm{C}\right)$} & \multirow{2}{*}{$\begin{array}{c}\text { Research } \\
\text { activity } \\
\text { level }\end{array}$} \\
\hline unit & & ${ }^{\circ} \mathrm{C}$ & $\mathrm{mg} / \mathrm{l}$ & & $\mathrm{mg} / \mathrm{l}$ & $\mathrm{mg} / \mathrm{l}$ & $\mathrm{mg} / \mathrm{l}$ & $\mathrm{mg} / \mathrm{l}$ & $\mathrm{mg} / \mathrm{l}$ & $\mathrm{mg} / \mathrm{l}$ & $\mathrm{mg} / \mathrm{l}$ & $\mathrm{mg} / \mathrm{l}$ & & & & \\
\hline 1 & Dolenjeske Toplice & 32.0 & 343 & 8.1 & 240 & 12.3 & 7.1 & 6.8 & 3.4 & 53.0 & 17.8 & 14 & $\mathrm{D}$ & W & - & V \\
\hline 2 & Jezero pri Družinski vas & 23.5 & 408 & 7.7 & 305 & 14.2 & 1.5 & 3.2 & 1.4 & 53.8 & 28.4 & 14.2 & D & W & - & V \\
\hline 3 & Klevevž & 25.0 & 478 & 7.4 & 363 & 9.8 & 1.5 & 2.0 & 0.8 & 58.5 & 28.4 & 4.2 & $\mathrm{D}$ & W & - & $\mathrm{V}$ \\
\hline 4 & Kostanjevica na Krki & 23.0 & 370 & 7.4 & 278 & 7.1 & 1.6 & 2.6 & 1.1 & 50.1 & 26.4 & 4.3 & $L$ & W & - & V \\
\hline 5 & Šmarješke Toplice & 33.5 & 433 & 7.1 & 292 & 19.7 & 4.3 & 4.0 & 1.5 & 55.1 & 28.6 & 13.8 & $\mathrm{D}$ & W & - & $\mathrm{V}$ \\
\hline 6 & Čatež & 64.0 & 360 & 7.5 & 262 & 11.5 & 2.7 & 6.0 & 3.4 & 45.6 & 26.5 & 26 & $\mathrm{D}, \mathrm{L}$ & W & - & $\mathrm{V}$ \\
\hline 7 & Varaždinske Toplice & 56.5 & 780 & 6.75 & 436.5 & 181.5 & 79.0 & 95.6 & 23.2 & 125.1 & 1.2 & - & $D, L$ & W & $>38.000$ & V \\
\hline 8 & Krapinske Toplice & 39.0 & 337 & 7.8 & 330.9 & 37.7 & 3.7 & 10.1 & 2.8 & 58.2 & 35.1 & - & D & W & 12.800 & V \\
\hline 9 & Stubičke Toplice & 61.5 & 426 & 6.6 & 300.4 & 89.7 & 12.8 & 27.9 & 7.1 & 71.7 & 24.2 & - & $\mathrm{D}$ & W & - & V \\
\hline 10 & Sveta Helena (Šmidhen) & 26.8 & 660 & 6.6 & 403.0 & 30.0 & 68.0 & 84.0 & - & 106.0 & 38 & - & $\mathrm{D}$ & W & 9400 & V \\
\hline 11 & Tuheljske Toplice & 32.9 & 445 & 7.3 & 367.8 & 35.8 & 4.9 & 11.2 & 3.1 & 64.6 & 34.9 & - & $L$ & W & - & V \\
\hline 12 & Dvorovi & 56.9 & 2104 & 6.8 & 843.18 & 38.4 & 513.9 & 580.9 & - & 45.0 & 21.24 & 37.9 & $\mathrm{~L}$ & W & - & $R$ \\
\hline 13 & Višegradska Banja & 34.8 & 426 & 7.4 & 270.85 & 14.4 & 4.7 & 11.6 & - & 55.3 & 21.3 & 40.9 & $\mathrm{~L}$ & W & $38.000 \pm 3.200$ & $\mathrm{~N}$ \\
\hline 14 & Olovo Banja & 35.0 & 572 & 6.2 & 311.6 & 28.8 & 6.0 & - & - & 180.0 & 45.5 & 31.2 & $\mathrm{~L}$ & $S$ & - & V \\
\hline 15 & Olovo Solun & 26.8 & 428 & 8.1 & 294.72 & 6.1 & 18.20 & 20.6 & - & 76.9 & 11.62 & - & $\mathrm{L}$ & $S$ & - & $\mathrm{N}$ \\
\hline 16 & Olovo Orlje & 24.6 & 320 & - & 223.98 & 3.1 & 13.00 & 2.4 & - & 73.7 & 3.87 & 0.2 & $\mathrm{~L}$ & $S$ & - & $\mathrm{R}$ \\
\hline 17 & Knežina llidža & 15.5 & 486 & 8.5 & 287.2 & 336 & 5.7 & - & - & 130.0 & 30.30 & - & $\mathrm{L}$ & $S$ & - & $R$ \\
\hline 18 & Budimlja Ilidža & 15.6 & 450 & 7.3 & 268.40 & 57.6 & 4.2 & 2.5 & - & 62.8 & 30.16 & - & $\mathrm{L}$ & $S$ & - & $\mathrm{R}$ \\
\hline 19 & Banja Luka-Slatina & 40.9 & 2911 & - & 1081.9 & 951.1 & 68.8 & 160.0 & - & 502.9 & 96.3 & 19.5 & $\mathrm{~L}$ & W & - & V \\
\hline 20 & Mala Kladuša & 25.0 & 592 & 6.5 & 384.9 & 14.4 & 22.7 & - & - & 75.0 & 87.98 & 3.5 & $\mathrm{~L}$ & W & - & V \\
\hline 21 & Čarakovo & 19.0 & 570 & 7.5 & 374.54 & 23.8 & 15.2 & 26.1 & 11.9 & 60.9 & 31.13 & 26 & $\mathrm{~L}$ & $S$ & - & $\mathrm{R}$ \\
\hline 22 & Laktaši & 30.4 & 528 & 6 & 603.8 & - & 6.7 & 23.8 & - & 135.8 & 26.5 & 0.1 & $L$ & W & - & $R$ \\
\hline 23 & Vrdnik & 33.0 & 890 & 7.5 & 555.0 & 90.0 & 28.0 & 69.0 & 7.1 & 60.0 & 67 & 10.0 & $\mathrm{~L}$ & W & - & V \\
\hline 24 & Ljuba & 22.5 & 730 & 7.5 & 491.1 & 22.0 & 17.7 & 23.9 & 2.7 & 90.0 & 45.1 & 14.0 & $\mathrm{~L}$ & $S$ & - & $P$ \\
\hline 25 & Debrc & 56.0 & 650 & 7.2 & 425.8 & 24.0 & 21.3 & 81.5 & 9.3 & 51.0 & 22 & 32.8 & $\mathrm{~L}$ & W & - & $P$ \\
\hline 26 & Dublje & 50.5 & 880 & 7.1 & 580.0 & 2.5 & 55.0 & 174.0 & 11.5 & 30.0 & 11 & 24.0 & $\mathrm{~L}$ & W & $20.000 \pm 500$ & $P$ \\
\hline 27 & Bogatić & 75.0 & 800 & 7.25 & 404.0 & 3.0 & 105.0 & 150.0 & 10.6 & 37.0 & 10.2 & 57.0 & $\mathrm{~L}$ & $W$ & $15.600 \pm 300$ & $P$ \\
\hline 28 & Banja Koviljača & 30.0 & 1400 & 6.6 & 890.0 & 55.0 & 89.0 & 200.0 & 22.2 & 120.0 & 36.6 & 18.0 & $L$ & W & $21500 \pm 600$ & V \\
\hline 29 & Paune & 21.2 & 500 & 7 & 353.0 & 5.0 & 11.0 & 4.6 & 0.5 & 90.0 & 18.3 & 14.0 & $\mathrm{~L}$ & $\mathrm{~S}$ & - & V \\
\hline 30 & Mionica & 26.0 & 600 & 6.5 & 372.0 & 24.0 & 7.1 & 102.0 & 4.2 & 29.0 & 12.5 & 24.0 & $L$ & W & 30.000 & V \\
\hline 31 & Vrujci & 26.0 & 460 & 7.4 & 235.0 & 0.9 & 14.2 & 16.0 & 1.7 & 39.3 & 17.9 & 12.0 & $\mathrm{~L}$ & W & $7.700 \pm 150$ & V \\
\hline 32 & Petnica & 31.0 & 340 & 7.5 & 378.0 & 14.0 & 7.0 & 14.3 & 1.9 & 80.0 & 24.4 & 16.0 & $L$ & W & $12.000 \pm 200$ & $P$ \\
\hline 33 & Banjci Kosjerić & 25.0 & 550 & 7.3 & 378.0 & 14.0 & 14.0 & 13.3 & 0.8 & 88.0 & 24.4 & 8.0 & L & $S$ & $6.000 \pm 120$ & $\mathrm{~N}$ \\
\hline 34 & Ovčar Banja & 36.5 & 640 & 7 & 456.0 & 18.0 & 14.0 & 13.0 & 2.5 & 102.0 & 32 & 25.0 & $L$ & W & $11.600 \pm 200$ & $\mathrm{P}$ \\
\hline 35 & Lađevac & 20.0 & 220 & 7.5 & 238.0 & 12.0 & 7.0 & 0.7 & 0.4 & 46.0 & 24.4 & 15.0 & $L$ & $S$ & $4.500 \pm 200$ & $\mathrm{R}$ \\
\hline 36 & Stapari & 21.0 & 400 & 7.2 & 334.0 & 1.0 & 7.1 & 1.0 & 0.3 & 80.0 & 15.3 & 10.0 & $\mathrm{~L}$ & $S$ & - & $\mathrm{N}$ \\
\hline 37 & Bioštanska Banja & 36.0 & 280 & 7.3 & 195.2 & 8.0 & 14.0 & 2.8 & 0.5 & 38.0 & 18.3 & 7.0 & $\mathrm{~L}$ & $\mathrm{~S}$ & - & $\mathrm{N}$ \\
\hline 38 & Roška Banja & 23.5 & 390 & 7.1 & 283.0 & 6.0 & 10.0 & 0.3 & 0.5 & 70.0 & 18 & 15.0 & $\mathrm{~L}$ & $S$ & - & $\mathrm{N}$ \\
\hline 39 & Banja Vapa & 17.5 & 342 & 7.1 & 379.0 & 3.0 & 19.9 & 10.5 & - & 109.5 & 11.5 & 3.0 & $\mathrm{~L}$ & $\mathrm{~S}$ & $8.750 \pm 160$ & $\mathrm{~N}$ \\
\hline 40 & Gostilje & 17.5 & 312 & 7.4 & 332.0 & 2.0 & 17.8 & 18.6 & - & 98.2 & 4.9 & 4.0 & $L$ & $S$ & - & $\mathrm{N}$ \\
\hline 41 & Visočka Banja & 25.0 & 350 & 7.5 & 256.2 & 4.8 & 5.0 & 3.5 & 0.4 & 62.0 & 15.8 & 12.0 & $\mathrm{~L}$ & $\mathrm{~S}$ & - & $\mathrm{N}$ \\
\hline 42 & Pribojska Banja & 36.0 & 420 & 7.2 & 294.0 & 8.0 & 7.0 & 6.0 & 0.6 & 60.0 & 24 & 18.0 & $L$ & $S$ & $28.000 \pm 1.000$ & V \\
\hline 43 & Crno Vrelo & 17.0 & 330 & 7.5 & 276.0 & 6.0 & 7.1 & 0.8 & 0.4 & 76.0 & 12.2 & 7.0 & $\mathrm{~L}$ & $S$ & - & $\mathrm{R} / \mathrm{N}$ \\
\hline 44 & Čedovo & 27.0 & 310 & 7.5 & 213.0 & 1.0 & 7.1 & 1.3 & 0.4 & 47.0 & 15.9 & 10.0 & $L$ & $S$ & $14.800 \pm 400$ & $\mathrm{R} / \mathrm{N}$ \\
\hline 45 & Rudnik Banja & 24.8 & 600 & 7.1 & 395.0 & 30.0 & 7.0 & 6.9 & 1.0 & 100.0 & 24 & 15.0 & $\mathrm{~L}$ & $S$ & - & $\mathrm{R} / \mathrm{N}$ \\
\hline 46 & Studenica & 25.0 & 670 & 7.1 & 488.0 & 8.0 & 10.0 & 17.0 & 1.0 & 105.0 & 33.5 & 12.0 & $\mathrm{~L}$ & $S$ & - & $\mathrm{R} / \mathrm{N}$ \\
\hline 47 & Čečevo & 24.0 & 690 & 6.7 & 465.0 & 14.0 & 7.0 & 10.8 & 1.3 & 135.0 & 12.2 & 10.0 & $\mathrm{~L}$ & $S$ & - & $\mathrm{R} / \mathrm{N}$ \\
\hline 48 & Pećka Banja & 23.0 & 2040 & 6.9 & 1420 & 10.0 & 52.0 & 252.0 & 5 & 145.0 & 86.0 & 60.0 & $\mathrm{~L}$ & W & - & $P$ \\
\hline
\end{tabular}

\section{Legend:}

Lithology

$\mathrm{L}$ - limestone

D - dolomite

- - no data

Occurrence

S- spring

W - well

\section{Research activity}

$\mathrm{N}$ - identified locality - not evaluated

$\mathrm{R}$ - regional evaluated deposit

$P$ - initiated detailed research

V-multi-purpose utilisation 


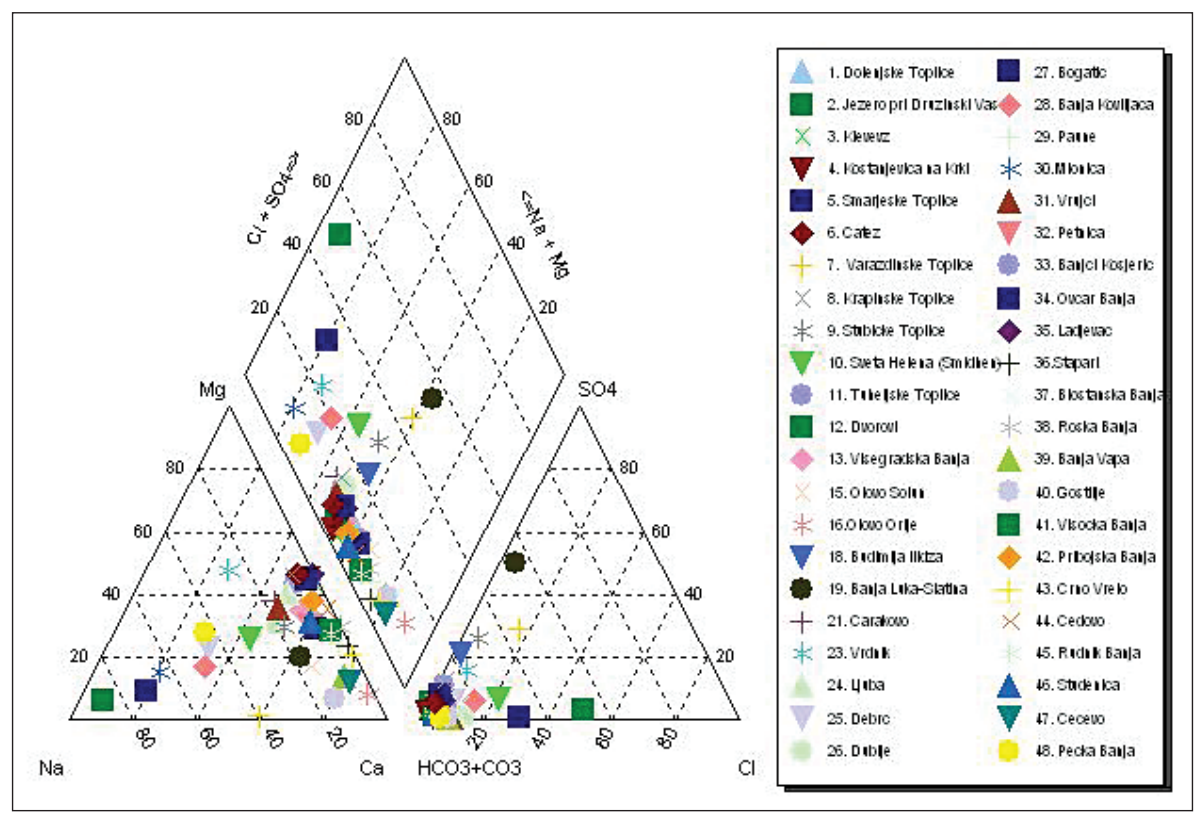

Fig. 4: Piper trilinear diagram of karst thermomineral waters of Inner Dinarides.

the water group characterised by neutral to poor alkaline reaction. Laktaši ( $\mathrm{pH} 6)$ and the Olovo Banja Spa (pH 6.2) belong to the water group with acid reaction, whereas the occurrences in Mionica (pH 6.5) and Mala Kladuša (pH 6.5) are at the boundary between acid and neutral reaction.

\section{BASIC GENETIC TYPES AND AGE OF WATER}

Thermomineral waters of the Inner Dinarides karst are classified, on the basis of anion-cation composition, into 13 types (Tab. 4). Hydrocarbonate ions prevail in anion composition of karst thermomineral waters of the Inner Dinarides (Tab. 4, Fig. 4). With the exception of occurrences in Dvorovi (Cl- $\mathrm{HCO}_{3}$ class), all thermo-

Tab. 4: Distribution survey of some genetic types of Inner Dinarides karst thermomineral waters.

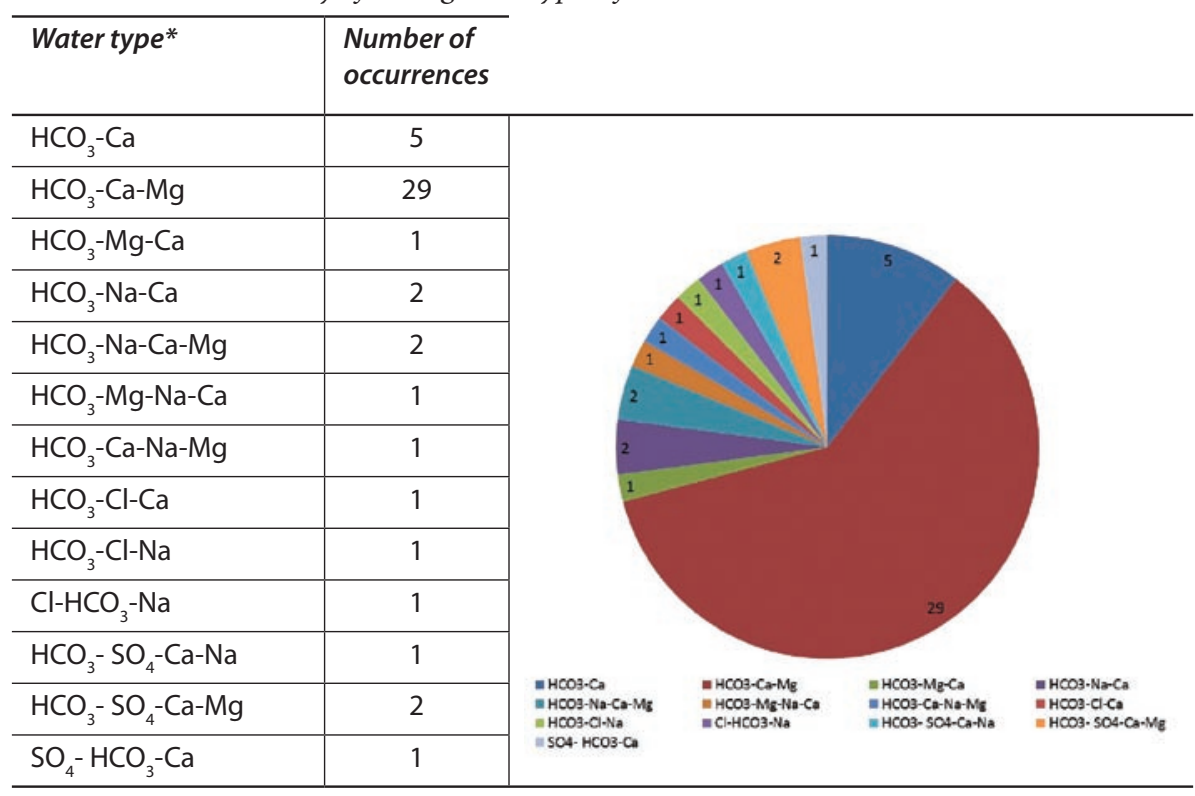

*after (Ivanov et al. 1964) mineral waters: Bogatić and Dublje $\left(\mathrm{HCO}_{3}-\mathrm{Cl}\right.$ class), the Stubičke Toplice Spa, the Varaždinske Toplice Spa and the occurrences of Budimlje-Ilidža $\left(\mathrm{HCO}_{3}-\mathrm{SO}_{4}\right)$ and Slatina-Banjaluka ( $\mathrm{SO}_{4}-\mathrm{HCO}_{3}$ class), are of a hydrocarbonate class. The primary aquifer of thermomineral waters in Dvorovi, Bogatić and Dublje is covered by

Neogene sediments reaching the depth of over $500 \mathrm{~m}$, very similar to those in the Pannonian Basin where waters of $\mathrm{HCO}_{3}-\mathrm{Cl}$ and $\mathrm{Cl}-\mathrm{HCO}_{3}$ classes are formed, thus there is certain hydraulic connection between thermomineral waters formed in the Sava Valley and karst thermal waters and the concentration of sodium in these waters is in favour of that. Unlike anion composition, where one water class prevails, in cation composition, several subclasses are noticeable (Tab. 4 , Fig. 4). The most numerous are thermomineral waters of the calcium-magnesium group (29 occurrences) and calcium groups (five occur- 
rences), which is typical of waters formed in a karst aquifer.

The age of some karst thermomineral waters of the Inner Dinarides has been determined on the basis of the isotope analysis (carbon ${ }^{14} \mathrm{C}$ ). The youngest waters are those from the Lađevac thermal spring $(4,500 \pm 200$ years), whereas the oldest karst thermomineral waters are of the Varaždinske Toplice Spa $>38,000$ years and thermomineral waters of the Višegradska Banja Spa $38,000 \pm 3,200$ years. It is interesting that the youngest thermomineral waters (Lađevac) are characterised by the lowest mineralization of all analysed waters of only $220 \mathrm{mg} / \mathrm{l}$, whereas the occurrences in the Varaždinske Toplice Spa and the Višegradska Banja Spa are characterised by almost two to three times higher mineralization than thermomineral water of the Ladevac spring. Thus, it can be concluded that the water exchange rate is one of essential factors affecting thermomineral water mineralization.

\section{GENESIS DISCUSSION ON BASIS OF D'AMORE PARAMETERS}

Using basic anions and cations D' Amore et al. (1983) determined six new parameters to determine water groups on the basis of geological characteristics of the main accumulations in each water sample, namely they suggested the application of new chemical parameters to define the groundwater genesis. Hydrochemical parameters are marked by letters from $\mathrm{A}$ to $\mathrm{F}$ and by the scope from $+100 \mathrm{meq} / \mathrm{l}$ to- $100 \mathrm{meq} / \mathrm{l}$. In addition to defining of the mentioned parameters, all analysed waters have been classified on the basis of geothermal systems in which they were formed (Hochstein 1988). D'Amore parameter diagrams for thermomineral waters from the geothermal system 2 and from the mixed geothermal system 1 and 2 are shown in Figs. 5 and 6.

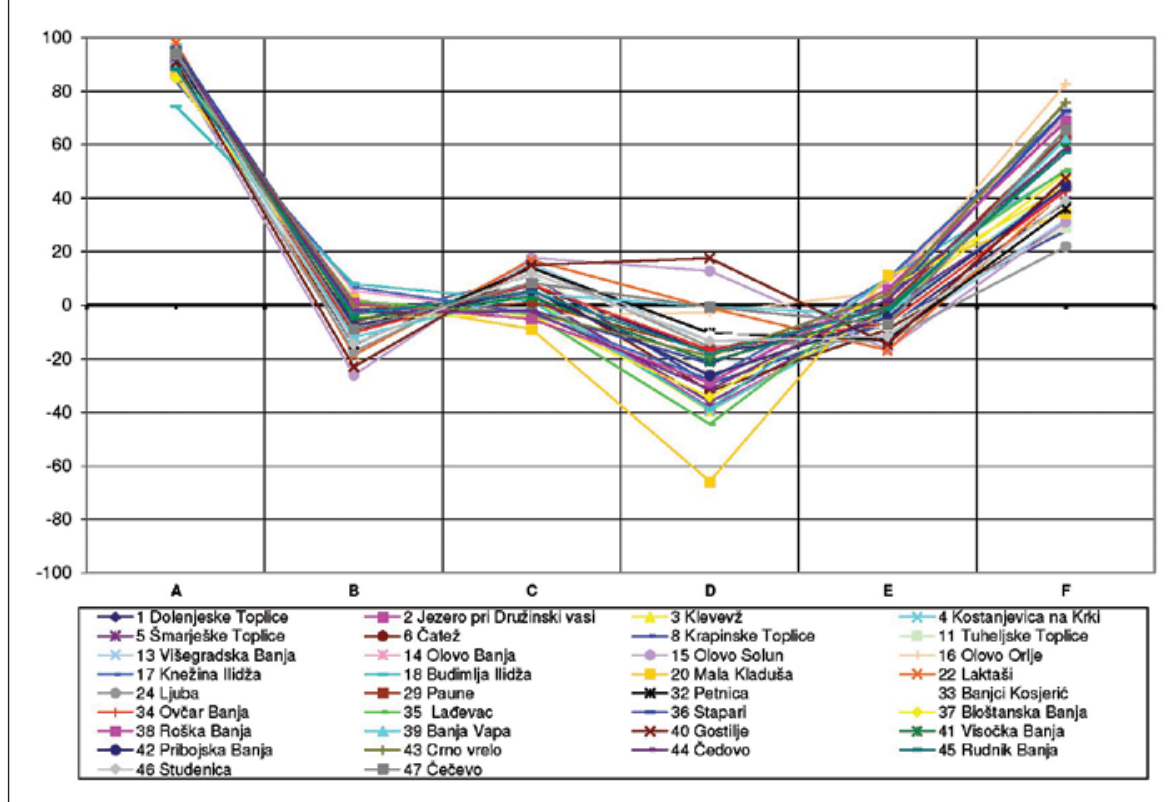

Fig. 5: D'Amore parameter diagram for karst thermomineral waters of Inner Dinarides from geothermomineral type 2 system (34 occurences).
In Tab. 5 and Fig. 7, there are presented D'Amore water types in relation to the geothermal system in which they were formed.

The largest number of karst thermomineral water occurrences (34 occurrences) was formed in the thermal system 2 and belongs to D'Amore b type (Tab. 5, Fig. 7), which is peculiar to waters formed in karst aquifers. The high value of the A parameter (Fig. 4) points out water circulation through carbonate, namely evaporite sediments. The low value of the B parameter points out that the karst water in its flow is not in contact with flysh and clay sediments. The values of the $\mathrm{C}$ parameter ranging from +18 to -10 , exclude the essential impact of flysh and clayey sediments in the formation of this water. The negative value of $\mathrm{D}$ parameter in the majority of analysed waters of $b$ type points out the possibility of water circulation through dolomite limestone. The value of the E parameter points out water movement through rocks that either may contain sulphates or are in contact with them. The high values of the $\mathrm{F}$ parameter point out that calcium content is significantly higher in relation to sodium and potassium content, which is the characteristic of waters formed exclusively in karst aquifers.

In addition to these prevailing phenomena, the complex geological setting of the Inner Dinarides region has conditioned the formation 


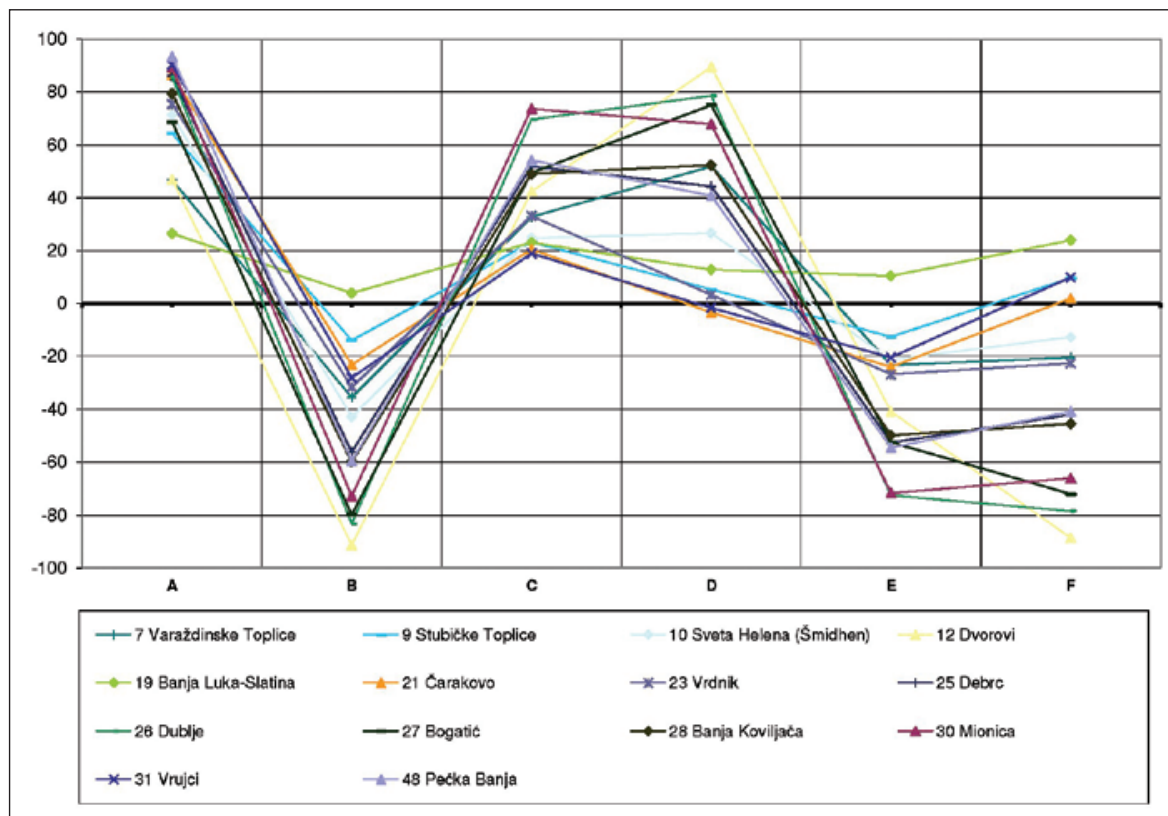

Fig. 6: D'Amore parameter diagram for karst thermomineral waters of Inner Dinarides from geothermomineral systems of type 1,2 (14 occurrences).

of complex hydrogeological systems in which there are thermomineral waters whose genesis is not related ex- clusively to karst terrains. 14 occurrences of thermomineral water are related to systems of this kind, of one and two types. Seven occurrences of thermomineral water (Debrc, Dublje, Bogatić, the Banja Koviljača Spa, Mionica, Vrujci and the Pećka Banja Spa) belong to the clastic water type (d type). It has been proved, by deep test drilling, that these waters are related to Triassic carbonate sediments. The common characteristic of the majority of listed thermomineral waters is that the Triassic carbonate complex in which the primary aquifer is formed is placed below the Neogene sediment package whose thickness reaches $500 \mathrm{~m}$ (Milivojević 1989), in which thermomineral water aquifers, similar to those in the Pannonian Basin are formed. Qualitative

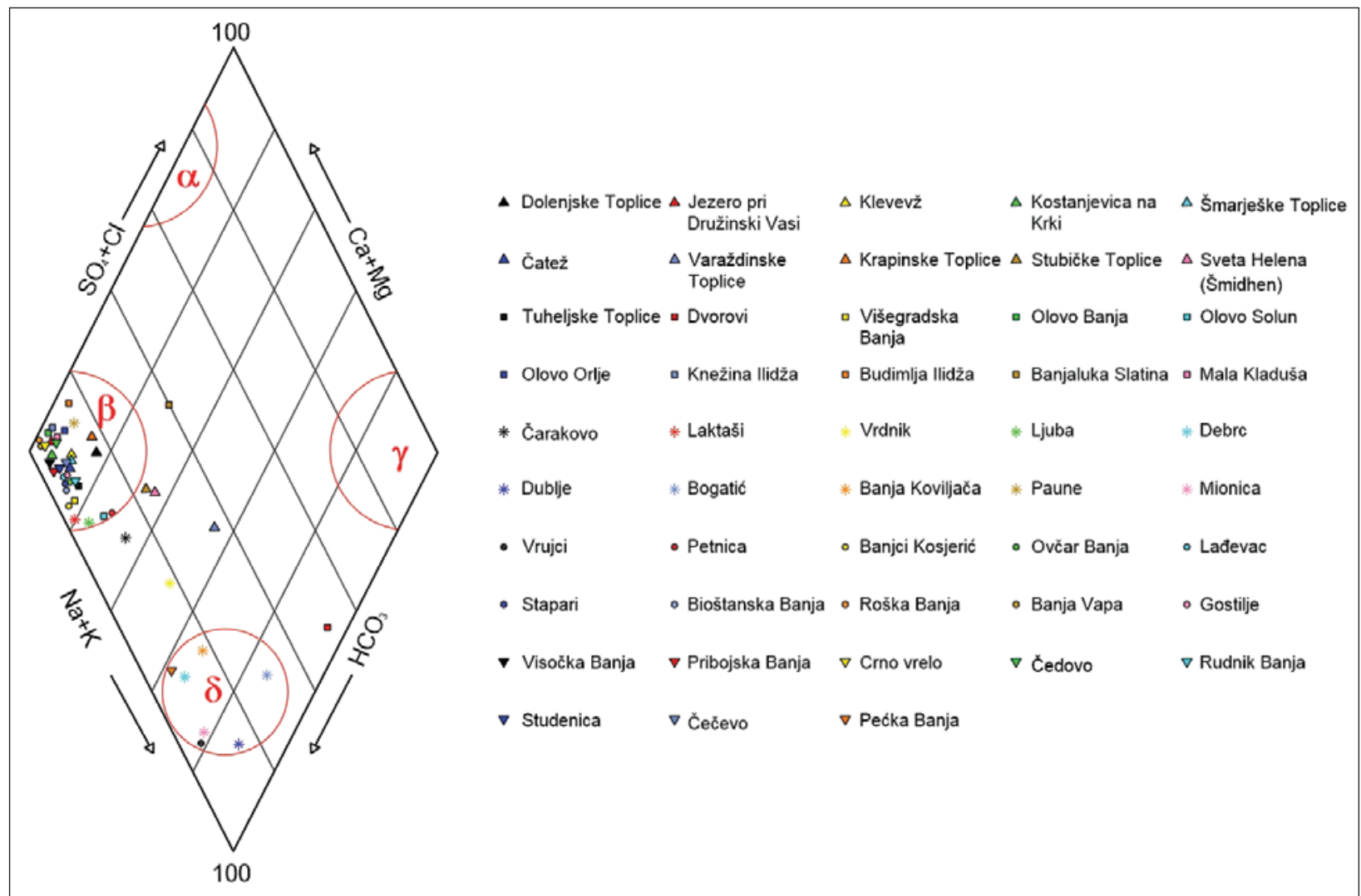

Fig. 7: Graphical survey of D'Amore- water types in the example of karst thermomineral waters of Inner Dinarides. 
Tab. 5: Survey of D'Amore-water types in relation to geothermal system type.

\begin{tabular}{|c|c|c|c|c|c|c|c|c|}
\hline & & \multicolumn{7}{|c|}{ D'Amore-water types } \\
\hline \multirow{6}{*}{$\begin{array}{l}\text { Thermal } \\
\text { system }\end{array}$} & & $\alpha$ & $\beta$ & $\gamma$ & $\delta$ & $\beta-\gamma$ & $\beta-\delta$ & $\gamma-\delta$ \\
\hline & 1 & - & - & - & - & - & - & - \\
\hline & 2 & - & 34 & - & - & - & - & - \\
\hline & 3 & - & - & - & - & - & - & - \\
\hline & 1,2 & - & - & - & 7 & 1 & 5 & 1 \\
\hline & $\Sigma$ & - & 34 & - & 7 & 1 & 5 & 1 \\
\hline
\end{tabular}

\section{LEGEND:}

\section{Thermal system}

1 - formed in sedimentary basins

2 - systems in carbonate sediments covered by rocks of poor water permeability

3 - systems formed in fissure environments at fault structure crossings

properties of the $d$ type thermomineral water point out hydraulic relation of a karst aquifer and a complex aquifer formed in the Neogene sediment package.

In addition to the water clastic type, within 1, 2 thermomineral systems, there were formed complex water types as well. The (b-d) type prevails among them. The formation mechanism of this water type is highly similar to the d type. Consequently, in case of the mixed water type (b-d) karst waters are in hydraulic relation to waters formed in clastic sediments, thus in case of these waters, the clastic water impact is lower.

The Slatina occurrence in the vicinity of Banja Luka is characterised by the mixed type (b-g). This occurrence is in contact with the ophiolitic zone of Central Bosnia which is separated from Triassic carbonate sediments by a deep fault. This dislocation is determined by gravimetric measurements in this part of the Banja Luka Tertiary
Basin. High water temperature $\left(40.9^{\circ} \mathrm{C}\right)$, a $\mathrm{SO}_{4}^{-} \mathrm{HCO}_{3}$ water type and the presence of $\mathrm{CO}_{2}$ point out the existence of a magmatic process (Josipović 1971).

The thermomineral water of a ( $\mathrm{g}$-d) type is distributed in Dvorovi. Although it was proved by deep test drilling that thermomineral waters in limestone are of Triassic age (Milivojević et al. 1996) qualitative properties of this water point that out. The impact on this water formation, similarly to thermal waters of the dype is certain hydraulic relation of waters formed in the Neogene sediment package with karst waters. A metamorphic component of these waters is related to the terrain tectonics.

The thermal system 3 waters and anhydrite type waters (a) are not distributed among thermal waters of the Inner Dinarides karst. Waters of the thermal system 3 are typical of fractured aquifers. Waters of this system are typical of terrains where young magmatic and neotectonic activities are developed, which is not the case with the Inner Dinarides region. One of basic characteristics of karst water is the prevailing presence of a hydrocarbonate anion, which automatically excludes the possibility of the anhydrite type water (a) formation.

\section{GENESIS DISCUSSION BASED ON CHARACTERISTIC GEOLOGICAL PROFILES}

In order to confirm the hypothesis on geological conditions as the prevailing factor in the formation of thermomineral waters of the Inner Dinarides, four typical cases of thermomineral waters were analysed, one in each state, in relatively uniform resolution (Fig. 8). Occurrences of thermomineral waters in Čatež, the Varaždinske Toplice Spa, the Višegradska Banja Spa and the Pribojska Banja Spa were analysed. General geological conditions of formation are shown in a graphic survey of characteristic profiles (Fig. 8).

In the beginning of hydrogeological research in the area of the Čatež Field, it was only known that thermomineral waters are in Quaternary sediments in the vicinity of the Terme Čatež Spa. The first research done in the year 1957 pointed out that there were several thermal water horizons in the Čatež Field. Water flows from Ter- tiary sediments, being in hydraulic relation with the deep thermal water-bearing horizon formed in Tertiary dolomites, to a Quaternary water-bearing horizon (Nosan 1973).

Thermomineral waters in the Varaždinske Toplice Spa are of a vadose origin and are mostly formed in Triassic dolomite and limestone. The Triassic carbonate complex is open on sufficiently large surfaces in the area of Kalničko Gorje (Šimunić 1988), which created a predisposition for the infiltration of large amount of atmospheric precipitation, thus the yield of thermomineral springs of $50 \mathrm{l} / \mathrm{s}$ is explained. The recharge zone of the Varaždinske Toplice Spa is on the altitude of 300 to $500 \mathrm{~m}$ higher than the discharge zone, which enables the formation of hydrostatic pressure resulting in thermomineral water discharge in the Varaždinske Toplice Spa area (Fig. 8). 


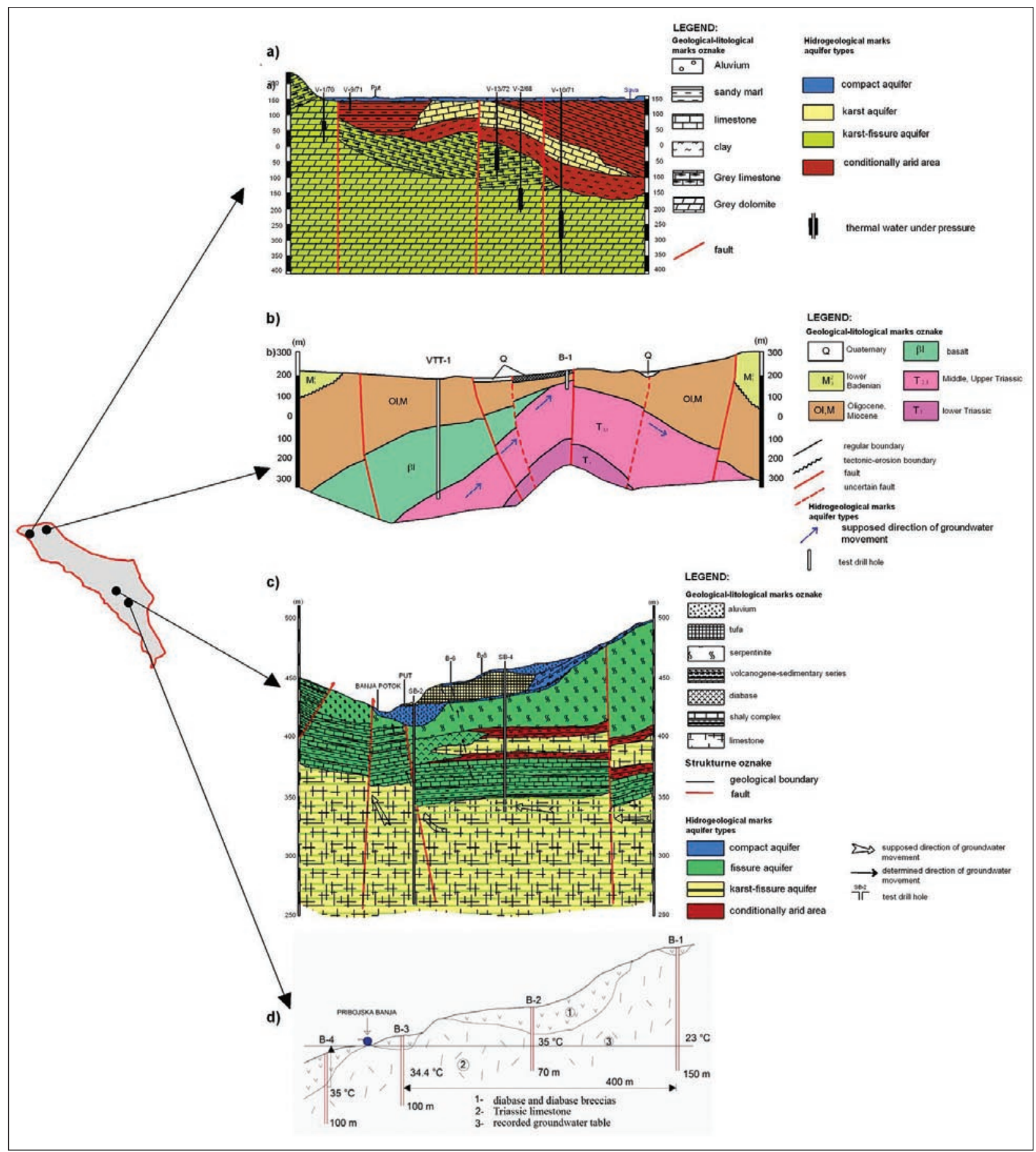

Fig. 8: Schematic geological profile of selected occurrences: a) Čatež, b) Varaždinske Toplice Spa, c) Višegradska Banja Spa and d) Pribojska Banja Spa (Sources: Nosan 1973; Šimunić et al. 2008; Miošić 1980; Grujić 1984).

The Višegradska Banja Spa area is made of peridotite, serpentinite, gabbro, diabase and carbonate sedimenats of Triassic age. Middle Triassic limestone is discovered south of the place of thermomineral water discharge in the Višegradska Banja Spa. The thermomineral water of the Višegradska Banja Spa is formed in limestone of
Triassic age underlying the shaly rock complex of diabase-horn slate formation and ultramafite (Fig. 8). The formation of thermomineral water of the Višegradska Banja Spa is conditioned by tectonics. At places of thermomineral water discharge there is tufa pointing out the existence of deeper water-bearing layers where there are 
interstices, fissures, and caverns of various dimensions, which has been confirmed by SB-2 and SB-4 test drill holes carried out in the Višegradska Banja Spa area in which limestone of Triassic age underlying the ultramafic rock complex was tapped (Miošić 1980).

The karst hydrogeological system of the Pribojska Banja Spa is developed in a half closed hydrogeological structure whose discharge was stated on three springs. Triassic limestone is surrounded by diabase and horn slate in the wider area of the Pribojska Banja Spa. The surface of opened karst in the wider area of the Pribojska Banja Spa amounts $2.85 \mathrm{~km}$ (Krešić 1987). It is obvious that such small surface of Triassic limestone cannot provide $50 \mathrm{l} / \mathrm{s}$ of thermomineral water. In the narrow zone of the Pribojska Banja Spa, there were carried out 10 test drill holes showing that Triassic limestone underlies diabase and horn slate as a rule (Fig. 8). Results of isotope analyses of Pribojska Banja Spa thermomineral water point out its considerable old age $(28,000 \pm 1,000$ years $)$ and a low degree of mixing with contemporary water, to which a stable temperature regime is in favour. All the facts point out that the recharge zone of Pribojska Banja Spa thermomineral water can be highly distant.

\section{AVAILABLE AMOUNTS AND TEMPEATURES OF KARST THERMOMINERAL WATERS}

According to collected data (Tab. 7), there are over 1,200 $1 / \mathrm{s}$ of thermomineral waters with the temperatures ranging from $15.5^{\circ} \mathrm{C}$ to $75^{\circ} \mathrm{C}$ in the Inner Dinarides karst area. This significant natural resource can be used for various purposes: as a geothermal energy resource, for balneological needs, in wellness programmes, for the needs of bottling and water supply.

The classification of thermomineral waters on the basis of temperatures is carried out respecting two criteria: geothermal and balneological (Tab. 6). On the basis of the geothermal criterion, thermomineral waters are classified into three groups $\left(<10^{\circ} \mathrm{C}, 10-30^{\circ} \mathrm{C},>30^{\circ} \mathrm{C}\right)$
(Milenić et al. 2009), whereas on the basis of the balneological criterion thermomineral waters are classified into hypothermal $<36$, homeothermic $36-37^{\circ} \mathrm{C}$ and hyperthermal $>37^{\circ} \mathrm{C}$ (Tab. 6).

From the geothermal aspect the largest number of occurrences (27) is in the temperature scope of $10-30^{\circ} \mathrm{C}$ where the utilisation of thermomineral water is possible for the needs of heating by means of heat pumps. Water with the temperatures over $30^{\circ} \mathrm{C}$ can be used for heating facilities directly without using heat pumps. 21 occurrences of thermomineral water are characterised by the temperature higher than $30^{\circ} \mathrm{C}$.

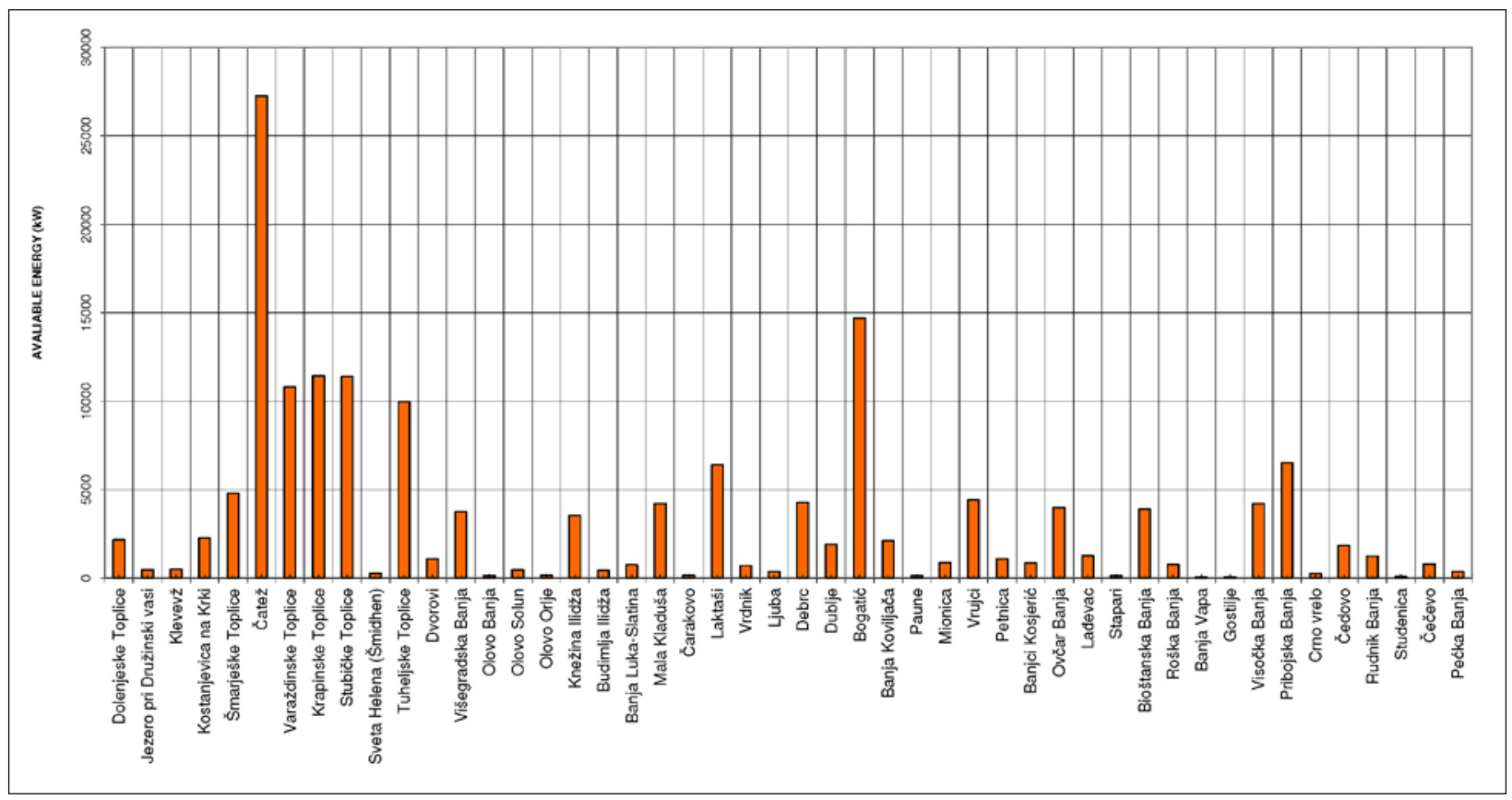

Fig. 9: Survey of available quantities of hydrogeothermomineral energy from karst thermomineral waters of Inner Dinarides. 
Tab. 6: Classification of thermomineral karst waters of Inner Dinarides on basis of temperature (Geothermal and Balneological Aspects).

\begin{tabular}{l|c|c|c|c|c|c|c}
\hline \multirow{2}{*}{$\mathrm{T}\left({ }^{\circ} \mathrm{C}\right)$} & \multicolumn{2}{|c|}{$<10^{\circ} \mathrm{C}$} & \multicolumn{2}{c|}{$10-30^{\circ} \mathrm{C}$} & \multicolumn{3}{c}{$>30^{\circ} \mathrm{C}$} \\
\cline { 2 - 9 } & $<4^{\circ} \mathrm{C}$ & $4-10^{\circ} \mathrm{C}$ & $10-20^{\circ} \mathrm{C}$ & $20-30^{\circ} \mathrm{C}$ & $30-36^{\circ} \mathrm{C}$ & $36-37^{\circ} \mathrm{C}$ & $>37^{\circ} \mathrm{C}$ \\
\hline Number Of Occurrences & - & - & 6 & 21 & 9 & 3 & 9 \\
\hline Geothermal Aspect & \multicolumn{2}{|c|}{0} & \multicolumn{3}{c|}{27} & & 21 \\
\hline \multirow{3}{*}{ Balneological Aspect } & \multicolumn{3}{c|}{ Hypothermal } & $\begin{array}{c}\text { Homoeo } \\
\text { thermic }\end{array}$ & $\begin{array}{c}\text { Hyper } \\
\text { thermal }\end{array}$ \\
\cline { 2 - 7 } & \multicolumn{3}{c|}{36} & 3 & 9 \\
\hline
\end{tabular}

Tab. 7: Available amounts of hydrogeothermomineral energy $(k W)$ from karst thermomineral waters of Inner Dinarides.

\begin{tabular}{|c|c|c|c|c|c|}
\hline No. & Name of occurrence & $T\left({ }^{\circ} \mathrm{C}\right)$ & $\Delta T\left({ }^{\circ} \mathrm{C}\right)$ & $Q(I / s)$ & $\begin{array}{c}\text { Available energy } \\
\text { amount (kW) }\end{array}$ \\
\hline 1 & Dolenjeske Toplice & 32 & 27 & 19 & 2154 \\
\hline 2 & Jezero pri Družinski vasi & 23.5 & 18.5 & 6 & 466 \\
\hline 3 & Klevevž & 25 & 20 & 6 & 504 \\
\hline 4 & Kostanjevica na Krki & 23 & 18 & 30 & 2268 \\
\hline 5 & Šmarješke Toplice & 33.5 & 28.5 & 40 & 4788 \\
\hline 6 & Čatež & 64 & 59 & 110 & 27258 \\
\hline 7 & Varaždinske Toplice & 56.5 & 51.5 & 50 & 10815 \\
\hline 8 & Krapinske Toplice & 39 & 34 & 80 & 11424 \\
\hline 9 & Stubičke Toplice & 61.5 & 56.5 & 48 & 11390 \\
\hline 10 & Sveta Helena (Šmidhen) & 26.8 & 21.8 & 3 & 274 \\
\hline 11 & Tuheljske Toplice & 32.9 & 27.9 & 85 & 9960 \\
\hline 12 & Dvorovi & 56.9 & 51.9 & 5 & 1089 \\
\hline 13 & Višegradska Banja & 34.8 & 29.8 & 30 & 3754 \\
\hline 14 & Olovo Banja & 35 & 30 & 1 & 126 \\
\hline 15 & Olovo Solun & 26.8 & 21.8 & 5 & 457 \\
\hline 16 & Olovo Orlje & 24.6 & 19.6 & 2 & 164 \\
\hline 17 & Knežina Ilidža & 15.5 & 10.5 & 80 & 3528 \\
\hline 18 & Budimlja Ilidža & 15.6 & 10.6 & 10 & 445 \\
\hline 19 & Banja Luka-Slatina & 40.9 & 35.9 & 5 & 753 \\
\hline 20 & Mala Kladuša & 25 & 20 & 50 & 4200 \\
\hline 21 & Čarakovo & 19 & 14 & 3 & 176 \\
\hline 22 & Laktaši & 30.4 & 25.4 & 60 & 6400 \\
\hline 23 & Vrdnik & 33 & 28 & 6 & 705 \\
\hline 24 & Ljuba & 22.5 & 17.5 & 5 & 367 \\
\hline 25 & Debrc & 56 & 51 & 20 & 4284 \\
\hline 26 & Dublje & 50.5 & 45.5 & 10 & 1911 \\
\hline 27 & Bogatić & 75 & 70 & 50 & 14700 \\
\hline 28 & Banja Koviljača & 30 & 25 & 20 & 2100 \\
\hline 29 & Paune & 21.2 & 16.2 & 2 & 136 \\
\hline 30 & Mionica & 26 & 21 & 10 & 882 \\
\hline 31 & Vrujci & 26 & 21 & 50 & 4410 \\
\hline 32 & Petnica & 31 & 26 & 10 & 1092 \\
\hline 33 & Banjci Kosjerić & 25 & 20 & 10 & 840 \\
\hline 34 & Ovčar Banja & 36.5 & 31.5 & 30 & 3969 \\
\hline 35 & Lađevac & 20 & 15 & 20 & 1260 \\
\hline 36 & Stapari & 21 & 16 & 2 & 134 \\
\hline 37 & Bioštanska Banja & 36 & 31 & 30 & 3906 \\
\hline 38 & Roška Banja & 23.5 & 18.5 & 10 & 777 \\
\hline 39 & Banja Vapa & 17.5 & 12.5 & 1 & 52.5 \\
\hline 40 & Gostilje & 17.5 & 12.5 & 1 & 52.5 \\
\hline 41 & Visočka Banja & 25 & 20 & 50 & 4200 \\
\hline 42 & Pribojska Banja & 36 & 31 & 50 & 6510 \\
\hline 43 & Crno vrelo & 17 & 12 & 5 & 252 \\
\hline 44 & Čedovo & 27 & 22 & 20 & 1848 \\
\hline 45 & Rudnik Banja & 24.8 & 19.8 & 15 & 1247 \\
\hline 46 & Studenica & 25 & 20 & 1 & 84 \\
\hline 47 & Čečevo & 24 & 19 & 10 & 798 \\
\hline 48 & Pećka Banja & 23 & 18 & 5 & 378 \\
\hline \multicolumn{5}{|c|}{$\Sigma$} & $\sim 160.000 \mathrm{~kW}$ \\
\hline
\end{tabular}

Available energy amounts that can be obtained from hydrogeothermal mineral systems of low enthalpy depend on water specific heat, groundwater temperature, namely temperature reduction that can be realised in a heat pump and the yield of a facility. This relation can be represented in the form of an equation by the following calculation:

$$
\mathrm{E}=\mathrm{C}_{\mathrm{p}} \cdot \mathrm{Q} \cdot \mathrm{DT}
$$

Where there is:

E - nominal available energy amount $(\mathrm{kW})$

$\mathrm{C}_{\mathrm{p}}$ - water specific heat (constant, $4.2 \mathrm{KJ} / \mathrm{kg} /{ }^{\circ} \mathrm{C}$ )

$\mathrm{Q}$ - yield of facility $(\mathrm{kg} / \mathrm{s}$, the same as $1 / \mathrm{s})$

DT - temperature reduction that can be realised in a heat pump

Thermomineral waters formed in karst aquifers of the inner Dinarides are characterised by geothermal potential of about $160 \mathrm{MW}$ (Tab. 7). 25 occurrences of Inner Dinarides karst thermomineral water have the geothermal potential of over 1MW (Fig. 9). 


\section{DISCUSSION ON TEMPERATURE PROGNOSIS IN RESERVOIRS BY GEOTHERMOMETER METHOD}

Geothermal potential of this significance, certainly, is not definite. It is calculated only for temperatures of the groundwater recorded so far. To determine complete geothermal potential, the geothermometer method was used for the sake of the calculation of primary temperatures in water-bearing horizons themselves (geothermal reservoirs).

Consequently, expected temperatures of karst thermomineral waters of the Inner Dinarides in "primary aquifers" have been calculated on the basis of geothermometer method based on chemical reaction in relation between a rock and water in relation to temperature. Method of hydrogeometers gives reliable results if the following conditions are fulfilled (Fournier et al. 1974):

1. chemical processes in an aquifer depending on temperature regulate element content used in the given geothermometer,

2. there is sufficiently high amount of reagent-mineral with the given elements,

3. chemical balance between water and a rock-mineral is established in an aquifer,

4. elements and their compounds used in geothermometer do not come into balance with the rock of an overlying aquafuge while water flows from the reservoir to the surface,

5. There is no mixing of thermomineral water with "cold" water from shallower aquifers.

In Tab. 8, there are presented results of expected temperatures of karst thermomineral waters of the Inner Dinarides in "primary aquifers" obtained on the basis of the geothermometer method (Tab. 8). In Tab. 8, it can be seen clearly that various geothermometers give various data for each of analysed systems. For example, silicon geothermometers give correct results with thermomineral waters characterised by neutral to low acid reaction, which is the case with the majority of karst thermomineral waters of the Inner Dinarides (Tab. 8). Unreliable, namely unreal data appearing with calculations for some occurrences (Pribojska Banja Spa, Mionica, Ovčar Banja Spa, Lađevac, Ljuba), are probably the concequence of mixing of thermomineral water with "cold" water.

Carried out calculations have shown that the Geothermometer $\mathrm{K} / \mathrm{Mg}$ is applicable for the occurrences: Čarakovo, Vrdnik, Mionica, the Ovčar Banja Spa and the Pećka Banja Spa where it has given corresponding results. The Geothermometer $\mathrm{Na}-\mathrm{K}-\mathrm{Ca}-\mathrm{Mg}$ is prone to making mistakes owing to the reaction between the water and the rock during water cooling on the way from the reservoir to the discharge zone.

Anomalous values of temperatures obtained by using some geothermometers are conditioned by high concentrations of magnesium in most analysed karst thermomineral waters of the Inner Dinarides.

It is clear, on the basis of the stated data, that geothermal potential is significantly higher than the one currently available. Therefore, far more detailed hydrogeological and hydrogeothemal explorations are required in the area of all thermomineral locations in the Inner Dinarides in order to evaluate the geothermal potential in the right manner. 


\section{POSSIBILITIES OF MULTI-PURPOSE UTILISATION IN EXAMPLE OF PRIBOJSKA BANJA SPA}

Thermomineral waters of the Pribojska Banja Spa, according to their quantitative and qualitative properties, offer a possibility for multi-purpose utilisation of this resource in terms of balneological-therapeutical, namely geothermal (heating of a therapeutic facility) aspects. Therefore the authors of this paper have completed the design of multi-purpose utilisation of the Pribojska Banja Spa thermomineral waters during the year 2010.
The Pribojska Banja Spa is situated in southwest part of Serbia. The natural wealth of the Spa comprises several factors: thermomineral water springs, altitude, and the formation of specific microclimatic conditions, a favourable geographical position. With regard to the listed factors, it is clear that the data on the existence and healing property of this area appear in some historical documents as early as $13^{\text {th }}$ century. The sanatorium, after

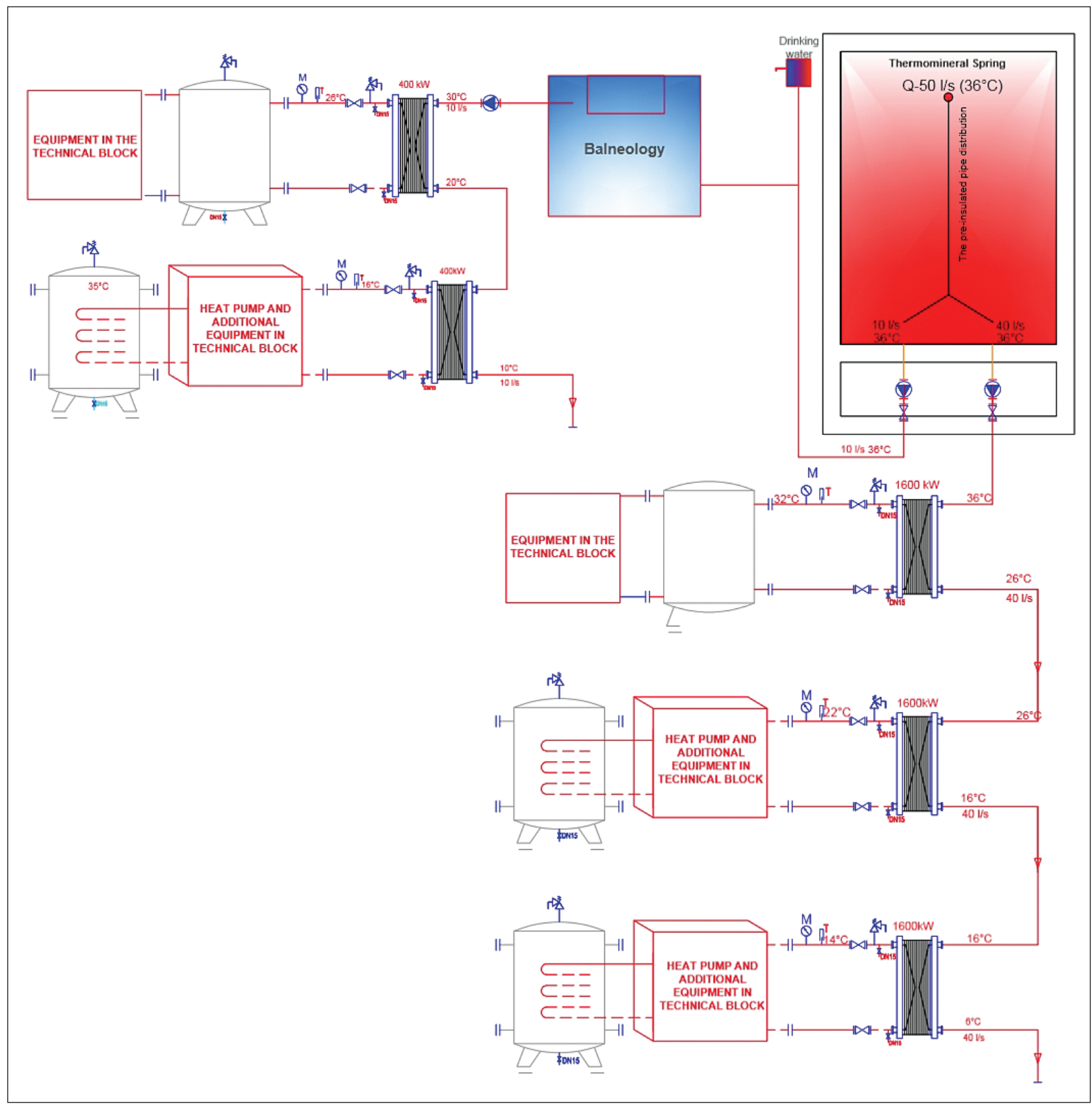

Fig. 10: Schematic survey system for multi-purpose utilisation of thermomineral waters in Pribojska Banja Spa (Milenić 2010). 
which the town has got its name Spa, lies across the plateau at the altitude of 530 to $550 \mathrm{~m}$ surrounded by Starovlaska mountains. The place is an air bath. In the very centre of the Spa, there is a seepage spring of thermomineral water with the water temperature of $36^{\circ} \mathrm{C}$. The Spa water is used as auxiliary therapeutic means, for bathing, and as drinking water. Thermomineral waters of the Pribojska Banja Spa are classified into the group of homeothermic ones of a hydrocarbonate-calcium-magnesium type.

Balneological-therapeutical aspect. The "per os"oral method (oral urography), namely bathing is applied for rehabilitation and treatment of patients in the Pribojska Banja Spa. The thermal water is used for treatment of the following diseases: post-traumatic state, chronic joint rheumatism and extra-joint rheumatism, peripheral nerve disorders, vertebral column, chronic gynaecological, skin diseases, digestive organs, gallbladder and urinary tract.

Geothermal aspect. Thermomineral waters with the amount of $50 \mathrm{l} / \mathrm{s}$ and the temperature of $36^{\circ} \mathrm{C}$ are a significant source of hydrogeothermomineral energy which can be used for the needs of heating. A low temperature heating system (wall and floor panels) using thermomineral water as the energy source is installed in the Rehabilitation Centre. The system is an example of cascade utilisation of groundwater presented in Fig.10.

The surface of the hospital for rehabilitation being heated is $1,900 \mathrm{~m}^{2}$. The consumption for the heating of this facility is $230 \mathrm{~kW}$, which is far below the energy amounts that can be obtained from thermomineral water in the Pribojska Banja Spa. Available water quantities are tapped from two arms. One arm taps $10 \mathrm{l} / \mathrm{s}$ and is carried away for Spa needs; afterwards it goes to the heat exchanger for the needs of the facility heating as well as for further Spa needs. The temperature regime in the primary circle of thermomineral water is $36^{\circ} \mathrm{C} / 30^{\circ} \mathrm{C}$. The other arm taps $40 \mathrm{l} / \mathrm{s}$ from where it is carried to the system of heat exchangers for the heating needs of facilities in the Pribojska Banja Spa. The first part of the design is completed. It is necessary to mention that available amounts of geothermal energy exceed the frames of the utilisation for the hospital needs, which offers the possibility to give connection to the heating system by hydrogeothermomineral energy to new consumers.

\section{CONCLUSIONS}

The basis of regional hydrogeological interpretation of karst thermomineral waters of the Inner Dinarides comprises geological setting and tectonic characteristics. Consequently, formation conditions of thermomineral water deposits essentially depend on geological setting of the terrain, namely the position and petrologic type of an aquifer within the geological setting. The area of the Inner Dinarides made mostly of limestone or more locally of dolomite rocks abounds in numerous thermomineral water occurrences. Thermomineral waters are similar as to their chemical characteristics, independently from localities of their occurrence. Temperatures range from $15.5^{\circ} \mathrm{C}$ (Knežina Ilidža) to $75^{\circ} \mathrm{C}$ (Bogatić). Karst thermomineral waters of the Inner Dinarides are characterised by mineralization which mainly does not exceed 1000 $\mathrm{mg} / \mathrm{l}$, neutral to low alkaline reaction (with the exceptions of Laktaši pH 6 and the Olovo Banja Spa pH 6.2). Generally, the feature of these waters is the prevailing presence of hydrocarbonate ions as well as calcium, and magnesium as prevailing cations.

Karst thermomineral waters of the Inner Dinarides are most frequently related exclusively to the type 2 geo- thermal systems formed in carbonate sediments covered by low water permeable rocks. In a certain number of thermomineral water occurrences, there occurs mixing owing to the existence of hydraulic connection between karst thermomineral waters and waters formed in sedimentary basins, thus it is impossible to determine only one geothermal system in which they are formed. Waters of this type are defined as thermomineral waters originating in geothermal systems 1 and 2. The analysis of D' Amore parameters has shown that the majority of karst thermomineral waters of the Inner Dinarides belong to the carbonate type (b) and they are, as a rule, formed in the geothermal system 1 . Waters of the d type (clastic water type) b-g (carbonate-metamorphic), b-d (carbonate-clastic), g-d (metamorphic-clastic), are formed in geothermal systems 1 and 2 .

Utilisation possibilities of karst thermomineral waters depend on their quantitative and qualitative properties. As waters characterized by increased temperatures are in question, the most rational way of their utilisation is "cascade" or "gradual" utilisation which is presented in the example of the Pribojska Banja Spa. 


\section{ACKNOWLEDGEMENTS}

This paper is conducted within the Project of the Ministry of Education and Science of the Republic of SerbiaResearch and Development of Renewable Groundwater
Resources in the Concept of Enhancing Energy Efficiency in Buildings (TR 33053).

\section{REFERENCES}

Aubouin, J., 1974: Des Tectoniques supeposees et de leur signification par rapport aux modeles geophysiques: l' exemple des Dinarides; paleotectonique, tectonique, tarditectonique, neotectonique.- Bull. Soc. Geol. France, 7, 15, 5-6, 426-460.

Andjelković, M., 1980: Tectonics of the Inner and Central Dinarides.- Faculty of Mining and Geology, pp.204, Belgrade.

Andjelković, M., 1988: Geology of Yugoslavia.- Građevinska knjiga, pp.692, Belgrade.

Cvijić, J., 1924: Geomorphology I.- National Printing House, pp.588, Belgrade.

Čičić, S. \& N. Miošić, 1986: Geothermal Energy of Bosnia and Herzegovina.- Special edition, Geoinženjering, pp. 205, Sarajevo.

Čvorović, Lj., 1970: Regularity of mineral, thermal, and thermomineral water occurrences in Bosnia and Herzegovina.- Master thesis, University of Sarajevo, pp.210, Sarajevo.

D’ Amore, F., Randifffio, G.S. \& C. Panichi, 1983: Some observations on the chemical classification of groundwaters.- Geothermics, Pergamon press Ltd., Vol. 12, No. 2/3., 141-148, Oxford.

Dimitrijević, M.D., 1995: Geology of Yugoslavia.- Geoinstitute, pp. 205, Belgrade.

Dragišić, V., 1997: General hydrogeology.- Faculty of Mining and Geology, pp. 434, Belgrade.

Filipović, B., 2003: Mineral, thermal and thermomineral waters of Serbia.- Serbian spas and resorts Association and Faculty of Mining and Geology, pp. 279, Belgrade.

Filipović, B., Krunić, O. \& M. Lazić, 2005: Regional hydrogeology of Serbia.- Faculty of Mining and Geology, pp. 401, Belgrade.

Fournier, R. \& A. H. Truesdell, 1974: Geochemical Indicators of Subsurface Temperature.- In: Estimation of Temperature and Fraction of Hot Water Mixed with Cold Water, Part 2, U.S. Geological Survey Journal of Research, Vol. 2, No.3, 263-270.
Fournier, R., 1977: Chemical geothermometers and mixing models for geothermal systems.- In: Proceedings of the International Atomic Energy Agency Advisory Group on the Application of Nuclear techniques to Geothermal Studies, Pisa, 1975.- Geothermics, Special issue, Vol. 5, 41-55, Pergamon Press, Oxford.

Fournier, R. \& R.W. Potter, 1979: Magnesium correction to the Na-K-Ca chemical geothermometer.- Geochim. Cosmochim. Acta, 43, 1543-1550.

Giggenbach, W., Gonfiantini R. \& C. Panichi, 1983: Geothermal Systems.- In: Guidebook on Nuclear Techniques in Hydrology, IAEA, 359-379, Vienna.

Grujić, P., 1984: Annual report on hydrogeological research of thermomineral waters of Pribojska Banja Spa for 1984 year.- Hidroprojekt, Report.

Group of authors, 1976: Geology of Serbia-Hydrogeology.Faculty of Mining and Geology, pp. 248, Belgrade.

Herak, M., 1977: Tecto-genetic approach to the classification of karst terrains.- Karst of Yugoslavia, 9, 4, 227-238.

Hochstein, P.M., 1988: Assessment and Modelling of Geothermal Reservoirs (Small Utilization Schemes).- Geothermics, 17, 1, 15-94.

Ivanov, V.V. \& A.G. Nevraev, 1964: Classification of the underground mineral waters.- Nedra, pp. 167, Moskva.

Josipović, J., 1971: Mineral, thermal and thermomineral waters in Bosnia and Herzegovina.- Bulletin geologique, 15, 233-277.

Kossmat, F., 1924: Geologie der zentralen Balkanhalbinsel.-Die Kriegsschauplatze 1914-1918 geologish dargestellt, 12, 1-198

Kranjc, A., 2004: Dinaric Karst.- In: Gunn, J. (ed.): Encyclopedia of Caves and Karst Science. Fitzroy Dearborn, 287-289, New York, London.

Krešić, N., 1987: Karstic hydrogeological systems in ophiolites belt of Inner Dinarides of Serbia.- PhD thesis, University of Belgrade, Faculty of Mining and Geology, pp. 210. 
Lapanje, A., 2006: Origin and chemical composition of thermal and thermomineral waters in Slovenia.Geologija, 49, 2, 347-370.

Mijatović, B. F. (ed.), 1984: Hydrogeology of the Dinaric Karst.- International contributions to Hydrogeology, Heise Verlag, vol. 4, pp. 255, Hannover.

Milenić, D., Vasiljević, P. \& A. Vranješ, 2009: Criteria for use of groundwater as renewable energy source in geothermal heat pump systems for building heating/cooling purposes.- Energy and buildings, 42, 5, 647-659.

Milenić, D., 2010: Pre-Feasibility Study of substitution of the existing heating system using direct thermomineral water at a rehabilitation centre Pribojska Banja Spa.- Faculty of Mining and Geology, University of Belgrade, Report.

Milivojević, M., 1989: Evaluation of geothermomineral resources of Serbia territory -excluding autonomous provinces.- PhD thesis, University of Belgrade, Faculty of Mining and Geology, pp. 478.

Milivojević, M., Cvijetić, R., Martinović M. \& S. Vukelić, 1996: Use of geothermal energy program in the $M Z$ Dvorovi.- Faculty of Mining and Geology, University of Belgrade, Report, pp. 246.

Miošić, N., 1980: Application of age detemination of thermomineral water of Višegradska Banja Spa by isotope method $14 \mathrm{C}$ and $3 \mathrm{H}$ in correlation with other explorations.- Geološki glasnik, 24-25.
Nosan, A., 1973: Thermal and mineral spring in Slovenia.- Geologija, 16, 81.

Petković, K., 1961: Tectonic map of FNR Yugoslavia.Glas SANU, Odelj. Prir. Mat. Nauka, 22, 129-144.

Protić, D., 1995: Mineral and thermomineral waters of Serbia.- Geoinstitut, Special publication book 17, pp. 269, Belgrade.

Radulović, M., 2000: Karst Hydrogeology of Montenegro.The Institute for Geological explorations of Montenegro, separate issues of Geological Bulletin, XVIII, pp. 271, Podgorica.

Stevanović, Z., 1995: Karst groundwater of Serbia-present and potential uses in regional water supply.- In: Stevanović Z. (ed.) Litospheric water mineral resources of Serbia, University of Belgrade, Faculty of Mining and Geology, pp. 77-121, Belgrade.

Šimunić, A., 1988: Sedimentary-petrographic analyses of samples from St-3 test drill hole in Sutinske Toplice and Nikolino Brdo in Topusko.- Croatian geological institute, Report, Zagreb.

Šimunić, A., 2004: Water Supply spas and mineral springs in the Croatian Zagorje.- Gazophylacium, XI, 3-4, 109-118.

Šimunić, A. \& I. Hećimović, 2008: Tuheljske toplice spa.In: Šimunić A. (ed.) Thermomineral and mineral Croatian water. Croatian geological institute, pp. 197-204, Zagreb. 